AIR COMMAND AND STAFF COLLEGE

AIR UNIVERSITY

\title{
“BEYOND-THE-BOX” THINKING ON FUTURE WAR: THE ART AND SCIENCE OF UNRESTRICTED WARFARE
}

\author{
by \\ João Vicente, Major, Portuguese Air Force \\ A Research Report Submitted to the Faculty \\ In Partial Fulfillment of the Graduation Requirements
}

Advisor: Dr. John T. Ackerman

Maxwell Air Force Base, Alabama

April 2009

Distribution A: Approved for public release; distribution unlimited. 


\section{Report Documentation Page}

Public reporting burden for the collection of information is estimated to average 1 hour per response, including the time for reviewing instructions, searching existing data sources, gathering and maintaining the data needed, and completing and reviewing the collection of information. Send comments regarding this burden estimate or any other aspect of this collection of information, including suggestions for reducing this burden, to Washington Headquarters Services, Directorate for Information Operations and Reports, 1215 Jefferson Davis Highway, Suite 1204, Arlington VA 22202-4302. Respondents should be aware that notwithstanding any other provision of law, no person shall be subject to a penalty for failing to comply with a collection of information if it does not display a currently valid OMB control number.

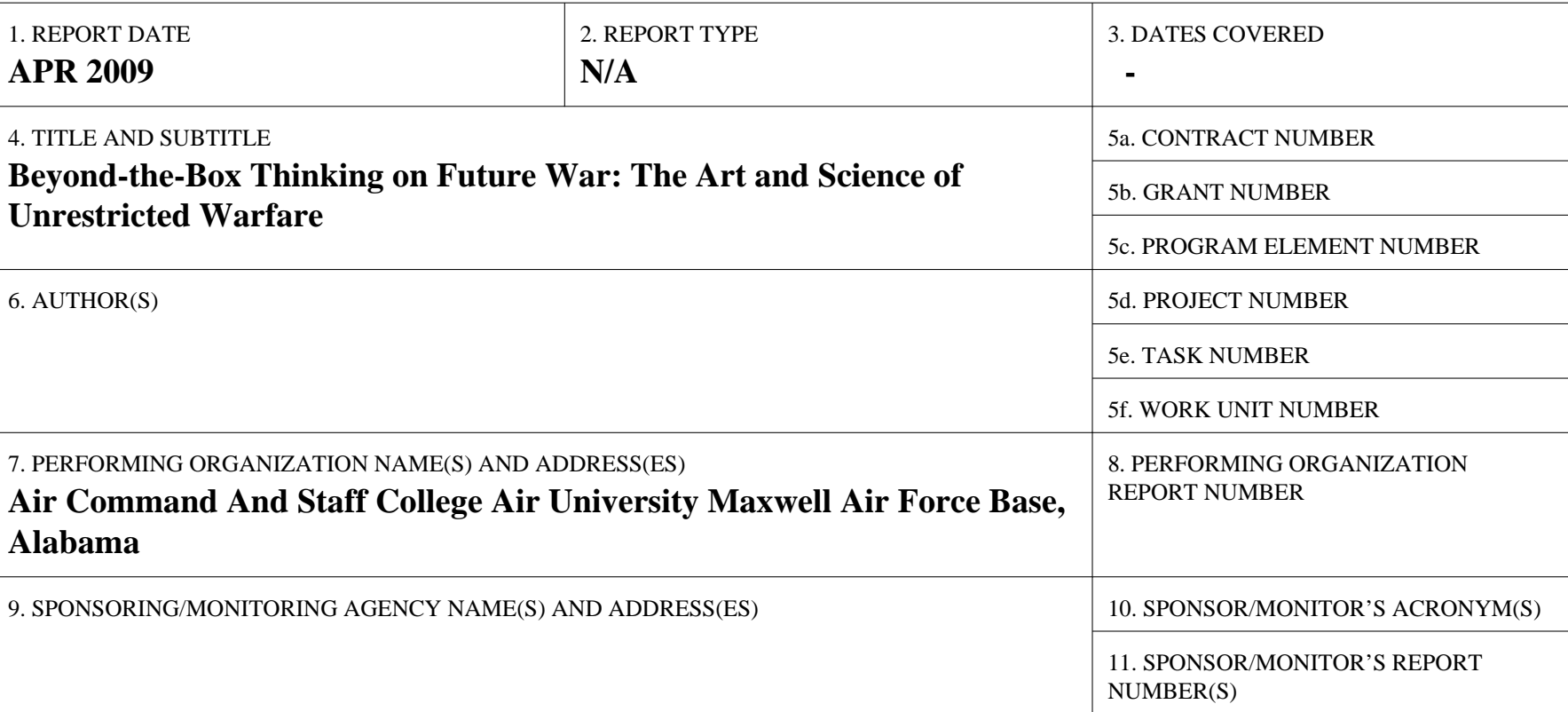

12. DISTRIBUTION/AVAILABILITY STATEMENT

Approved for public release, distribution unlimited

13. SUPPLEMENTARY NOTES

14. ABSTRACT

Globalization, the technological interconnectedness of societies, and Americas military prowess have created the opportunity and motive for future peer competitors to exploit Unrestricted Warfare (URW) strategies. This holistic approach to warfare employs coherent and integrated multidimensional actions, synchronized in time and space, combining all available means, including military and civilian, violent and non-lethal force, targeting adversarys wide-spectrum domains, aiming to affect opponents will and capabilities during times of real or perceived conflict. Shifting the emphasis from military to political, economic, information, and cultural engagements, future peer competitors will aim to constrain the USs response within a regional or global sphere of interest, degrading its combat effectiveness, by collapsing government organizations, and disrupting the normal flow of society. Such perspective produces several strategic implications, exposing legal and moral dilemmas, the increasing civilianization of war, and risk society challenges. The fact that warfare is expanding beyond the military domain continues to constrain Western thought, challenging military and political decision-makers. Therefore, it demands a shift of mindset in order to understand that the main strategic differences towards warfare are cultural, and that warfare should be viewed as a holistic endeavor. Hence, the importance of a coherent integration of USs national security strategy. This involves a three step approach based on renewed strategic thought, the purposeful adaptation leading to a holistic-agency approach, and a people-centric perspective enhancing the education of the national security practitioners.

15. SUBJECT TERMS

16. SECURITY CLASSIFICATION OF:

a. REPORT

unclassified b. ABSTRACT unclassified
17. LIMITATION OF ABSTRACT

SAR
18. NUMBER 19a. NAME OF

OF PAGES RESPONSIBLE PERSON c. THIS PAGE unclassified 
Standard Form 298 (Rev. 8-98) Prescribed by ANSI Std Z39-18 


\section{DISCLAIMER}

The conclusions and opinions expressed in this document are those of the author. They do not reflect the official position of the US Government, Department of Defense, the United States Air Force, or Air University. 


\section{Contents}

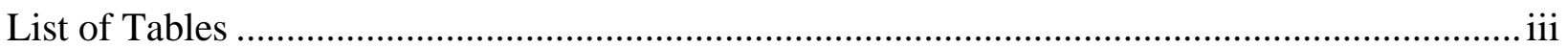

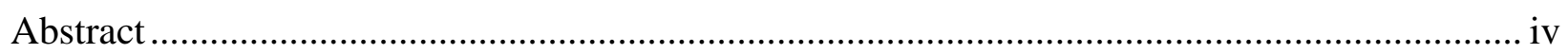

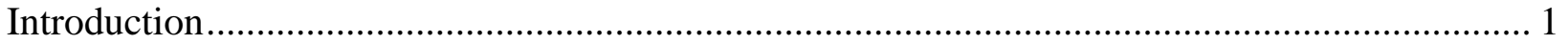

Framing the Problem: Exploring the Drivers of Future Warfare ............................................... 3

The New American Way of War............................................................................... 3

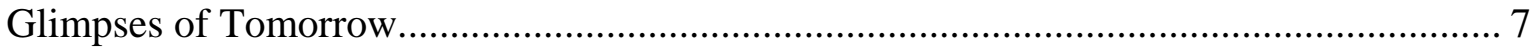

The Art and Science of Unrestricted Warfare...................................................................... 9

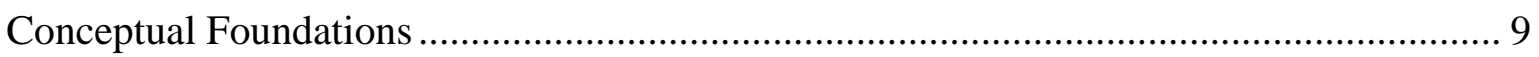

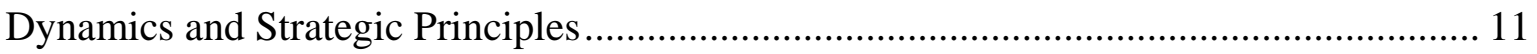

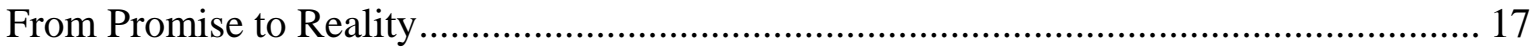

Strategic Implications of Unrestricted Warfare ........................................................... 20

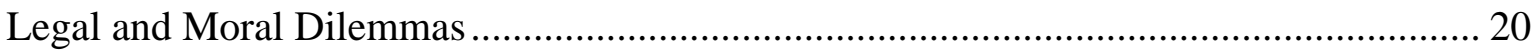

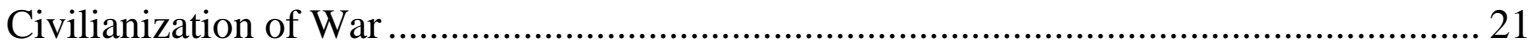

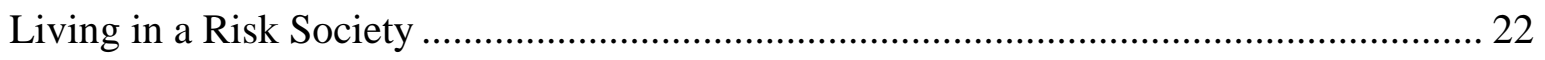

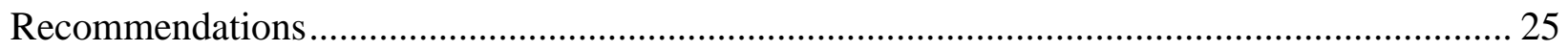

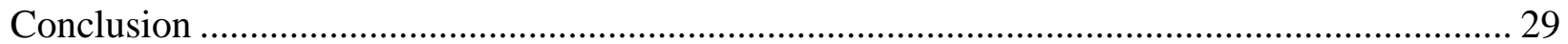

Appendix 1: Unrestricted Warfare Methods.............................................32

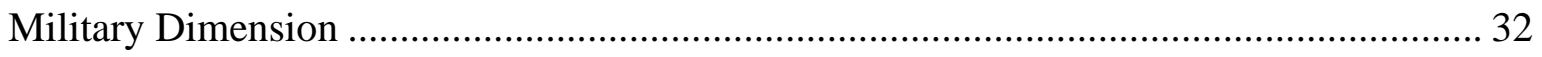

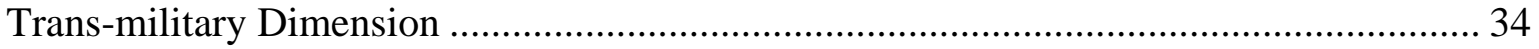

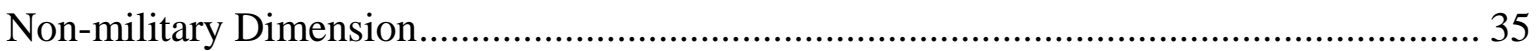

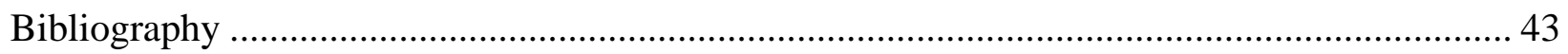


AU/ACSC/1172/AY09

\section{List of Tables}

Table 1. Examples of Unrestricted Warfare Methods..................................15 


\begin{abstract}
Globalization, the technological interconnectedness of societies, and America's military prowess have created the opportunity and motive for future peer competitors to exploit Unrestricted Warfare (URW) strategies. This holistic approach to warfare employs coherent and integrated multidimensional actions, synchronized in time and space, combining all available means, including military and civilian, violent and non-lethal force, targeting adversary's widespectrum domains, aiming to affect opponent's will and capabilities during times of real or perceived conflict. Shifting the emphasis from military to political, economic, information, and cultural engagements, future peer competitors will aim to constrain the US's response within a regional or global sphere of interest, degrading its combat effectiveness, by collapsing government organizations, and disrupting the normal flow of society. Such perspective produces several strategic implications, exposing legal and moral dilemmas, the increasing civilianization of war, and risk society challenges.

The fact that warfare is expanding beyond the military domain continues to constrain Western thought, challenging military and political decision-makers. Therefore, it demands a shift of mindset in order to understand that the main strategic differences towards warfare are cultural, and that warfare should be viewed as a holistic endeavor. Hence, the importance of a coherent integration of US's national security strategy. This involves a three step approach based on renewed strategic thought, the purposeful adaptation leading to a holistic-agency approach, and a people-centric perspective enhancing the education of the national security practitioners.
\end{abstract}




\section{Introduction}

It's the end of war as we know it! Imagine a future scenario where an adversary devises a plan to strike the United States (US) using a holistic approach. In the midst of a global economic meltdown, and avoiding direct military confrontation, the adversary unleashes a series of coordinated network attacks against critical infrastructures. Several Trojan horses are activated creating havoc on air traffic control, nuclear power plants, electricity facilities, and financial markets, shutting down the country. This chaotic environment creates the opportunity for 'cyber moles' to target sensitive corporate data, stealing valuable intellectual property. Meanwhile, a fully-loaded oil tanker is hijacked by a private military company and sunk in the Gulf of Mexico creating an ecological catastrophe. Suddenly, several cases of viral infections are diagnosed as the outbreak of smallpox rapidly spreads around the country causing a biological epidemic. In the meantime, several stories of food poisoning start circulating in the media increasing the population uproar. This farfetched scenario portrays a large-scale asymmetric attack on the US by an ambiguous peer competitor with the intent to paralyze society and cause social panic and unrest leading to a political crisis. The peer competitor's ultimate goal would be to constrain the US's interests and freedom of action, on either a global or regional basis. ${ }^{1}$

The prospect of a war-free world has its roots on the promises of technological advances that would render future combat obsolete. ${ }^{2}$ However, the question is not how technologically advanced a society is but what it does with that technology. The lethality, precision, and global reach of the American way of war has changed the modern character of warfare, allowing the US to fight wars with fewer casualties. This trend has created a military asymmetry which expresses the limited effectiveness of conventional warfare against the overwhelming conventional power of American military forces. 
Such a framework unveils a fundamental problem, which underlines this research. Given the tendency of the US to pursue the hi-tech approach to warfare and the effects of future trend drivers such as globalization and technology, what strategy can a peer competitor develop to compensate for military inferiority to the US? Furthermore, it is an assumption of this study that the rise of a peer competitor will not be peaceful, and it will bring severe consequences to the security of the US. This dilemma spurs several derived questions which will stimulate and guide this research. What are the drivers of future warfare and how will they interact with the American way of war to create opportunities for a future peer competitor? What are the principles, dynamics, dilemmas, and strategic utility of such strategy? What are the implications for the US and the future of warfare? What can the US do about it?

Bounded by such a framework, this research will argue that future adversaries of the US will utilize Unrestricted Warfare (URW) strategies in order to avoid direct confrontation with US military forces. The URW strategies utilized will leverage all state instruments of power and warfare will not be restricted to just military targets. Overall, this holistic strategy will be a viable tool to accomplish national security objectives when a weaker state confronts a more powerful state. ${ }^{3}$ Ten years have passed since the concept of URW was initially introduced by two Chinese Colonels. ${ }^{4}$ Instead of "using armed force to compel the enemy to submit to one's will," they envisioned future warfare as a holistic approach reflecting the employment of "all means, including armed force or non-armed force, military and non-military, and lethal and nonlethal means to compel the enemy to accept one's interests." ${ }^{5}$ Since then, several events have provided sufficient insights to suggest the prospective character of this theory of warfare as a cornerstone for future interstate conflict. On the other hand, recent conflicts have revealed some of the military and political weaknesses of the American way of war. ${ }^{6}$ Exploiting those 
weaknesses will be the main focus of future strategies available to peer competitors of the US. Will America be ready?

The problem-solution methodology will guide the research effort. In order to establish a structured way to collect and analyze information, Strengths, Weaknesses, Opportunities, and Threats (SWOT) analysis will be introduced as a strategic planning tool to evaluate the proposed solution. ${ }^{7}$ This activity is designed to exercise proactive thinking, thus improving the understanding, discussion, and decision-making process. This paper will frame the problem by exploring the tendencies of the American way of war and investigating the effects of global trends, with the purpose of discovering the strategic opportunities for the rise of URW. Afterwards, it will establish the conceptual foundations of URW, describing its origins, characteristics, and impact, using a reasoning pattern to predict some of its implications. Finally, it will offer some prescriptive recommendations.

\section{Framing the Problem: Exploring the Drivers of Future Warfare}

\section{The New American Way of War}

Investigating the traits of America's current approach to combat provides a framework to understand its future behavior. It also exposes some of the continuities and tendencies that can be exploited by future adversaries. The discussion evolves within several trends such as the pursuit for decisiveness of the military instrument; the centrality of technology as a solution to the strategic problems; the growing cost of warfare; the casualty aversion; and the tendency to wage war as an autonomous endeavor.

The quest for decisive battles, relying on a maneuver and firepower approach with emphasis on technology has been the hallmark of the American way of war. The seminal work of Russell 
Weigley establishes the historical patterns of the American way of war as defaulting to a strategy of annihilation, which seeks to overthrow the enemy’s military power mainly through conventional battles. ${ }^{8}$ Others debate this aspiration for annihilation, claiming that throughout its history the US has favored attrition strategies. ${ }^{9}$ Reflecting on the tradition of fighting small wars and insurgencies, Max Boot broadens this scope arguing for a new American way of war. One that avoids bloody matches and seeks victory in a quicker and safer way, through speed, maneuver, flexibility, and surprise. ${ }^{10}$ Giving as an example the invasion of Iraq, he unveils the role of information technology, precision firepower, Special Forces, psychological operations, and jointness. Steven Metz confirms the importance of speed, knowledge, and precision in reducing casualties and leading to the rapid resolution of wars. ${ }^{11}$ However, in recent years, he has acknowledged that these qualities were not enough to provide a quick strategic success. ${ }^{12}$

The pursuit of a technological solution to the strategic challenges is deeply enrooted in the American way of war. ${ }^{13}$ In part because the fascination with technology assumes it will dictate the character of future warfare. ${ }^{14}$ Thomas Mahnken confirms the overwhelming advantage of the US's technological edge over friend and foe alike. ${ }^{15}$ Technological innovation played a decisive role during World War II, providing also the qualitative advantage over the Soviet Union during the Cold War. This trend was reinforced in recent conflicts where increased lethality, precision, and global reach have highlighted the promises of technology. In reality, technological superiority may have become a disadvantage by creating the perception that wars are clean, safe and acceptable. ${ }^{16}$ It is a fact that technological advances introduce asymmetries on the battlefield. ${ }^{17}$ Unfortunately, where one sees strengths others see weaknesses. These advantages have always been temporary and rapidly equalized, either by new technologies or fighting tactics. $^{18}$ For example, during Vietnam, in order to negate American technological supremacy, 
the adversary shifted the battlefield to complex environments, such as urban, jungle or mountains. ${ }^{19}$ Again, history repeats itself in recent conflicts, where potential adversaries are not hampered by bureaucracy and can fully exploit commercial technology. ${ }^{20}$ Armed with a computer, modem, and a stolen credit card, any enemy is only bounded by their imagination. ${ }^{21}$ Hence, this machine mindedness, as expressed by Colin Gray, exposes past, present, and future trends of American warfare. ${ }^{22}$

Directly related with the technological prowess is the claim that America has often won its wars by outspending its adversaries. ${ }^{23}$ Because the US has chosen to be strong in every sphere of combat, in every type of warfare, and in every corner of the globe, it faces pressure to invest and innovate in many different fields at once. ${ }^{24}$ This ambition comes with a price tag. For example, in 2007 the amount of the US's military budget was higher than at any time since World War II. ${ }^{25}$ However, due to the growth of the US economy, the burden of military spending is lower when compared with the peak spending years of the Cold War. ${ }^{26}$ Yet, the costs associated with the American way of war may seem acceptable because of its precision, lethality, and reduced casualties. Although the cost per weapon has increased, the promise of improved efficiency with fewer personnel and equipment makes it a political instrument of choice. ${ }^{27}$ Nevertheless, the competition for funds, the escalating costs of weapon systems programs, the delays in the development and the replacement of legacy systems pose additional constraints to the defense budget, either by reducing the number of systems produced, or by accepting less operational capability than expected while extending the production timeline. ${ }^{28}$

Another main theme of the American way of war is the aversion to casualties, both friendly and collateral. The reasons for this are twofold. First, it reflects the trend of risk-averse societies, where small families lacking expendable children have lower tolerance for casualties. ${ }^{29}$ 
Second, it is a consequence of the improved precision and lethality of the American way of war, creating the expectations for a casualty-free warfare. ${ }^{30}$ These trends diminish the likelihood that advanced societies will deliberately set out to fight one another unless they can be convinced that war can be waged with fewer soldiers. ${ }^{31}$ Some may see this as a weakness worth exploiting. For example, the US intervention in Somalia revealed an extremely cautious approach to the use of force, giving the insurgents the opportunity to exploit the American casualty-aversion as a weakness. Nonetheless, this casualty sensitivity must be seen in context. Whenever society perceives that vital interests are at risk it will be more permissive of casualties. Historical examples of World War II and the initial response after 9/11 support this claim. Nevertheless, the expectation for a quick and decisive victory, although seldom real, is an image that many Americans want and expect. ${ }^{32}$ Hence, in an era of the 24 hours news cycle coupled with a strategic nearsightedness of a democratic regime, which is captive to electoral cycles, it becomes difficult to lead and justify a long war unless there is a clear and present danger. ${ }^{33}$

Several authors are inclined to agree with Antulio Echevarria's argument that the American way of warfare reflects a symptomatic military approach that concentrates on winning battles instead of wars. ${ }^{34}$ Wielding military power autonomously from other instruments of power is a consequence of different spheres of responsibility, one for diplomacy and one for combat. ${ }^{35}$ Colin Gray reinforces these trends in his analysis about the American way of war, suggesting the need for additional efforts thinking about the capabilities needed to turn combat successes into favorable strategic outcomes. ${ }^{36}$ These lessons are painfully expressed throughout history, revealing some of the weaknesses of the American way of war when confronted with unconventional methods of warfare. ${ }^{37}$ 
AU/ACSC/1172/AY09

\section{Glimpses of Tomorrow}

Exploring future trends and its drivers provides insights that will be helpful to frame the research problem. Having in mind the complexity, and sometimes the impossibility, of predicting the future, the following discussion addresses the emergence of a multipolar future and the shift of the US's hegemony. The interaction of globalization and technology diffusion will impact warfare’s diversity, affordability, and effectiveness. Further analysis reveals the potential for interstate conflicts as a result of geopolitical rivalry, within a resources constrained, over-populated world, facing an environmental crisis.

Global Trends 2025: A Transformed World is the most current study released by the National Intelligence Council. ${ }^{38}$ The major assumption in this report is that the emergence of a multipolar future brings dramatic changes to the international system. ${ }^{39}$ Greater diffusion of authority and power could occur, creating a global governance deficit. ${ }^{40}$ This is also the opinion of several authors which assert the shift of US hegemony. ${ }^{41}$ Not necessarily due to American decline but rather due to the rise of other powers. The rise of China, European Union, Brazil, Russia, and India will increase the clashes over states interests. Additionally, the predicted reduction of effectiveness of international institutions could narrow the scope of the US's policy options. $^{42}$ Although still possessing military superiority, in 2025 the US could be confronted by asymmetrical strategies, trying to exploit military and political vulnerabilities, with the objective to constrain the US's freedom of action in time of crisis. ${ }^{43}$

Globalization remains the pervasive meta-trend which may reorder "current divisions based on geography, ethnicity, and religious and socio-economic status."44 Additionally, globalization could continue to ensure the diffusion and affordability of technology, which would facilitate the disruption of advanced societies. The trend of technological diffusion, both in proliferation and 
reduced cost, could then allow what Dennis Bushnell calls “warfare on the cheap," ensuring that any nation or sizable organization can achieve a very worrisome military peer status. ${ }^{45}$

Therefore, in the future, technology could improve warfare's affordability and effectiveness. During most of the twentieth century, military technology outpaced civilian technology, but with the arrival of the information age that trend has reversed. ${ }^{46}$ Today, industry is the largest source of research and development (R\&D) funding. ${ }^{47}$ In the future, the continuing trend of shifting investment in technology $\mathrm{R} \& \mathrm{D}$, from the government to the private sector, may increase the dependency of the military on commercial technologies and services. On the other hand, it could make those technologies readily available to possible adversaries. For illustration, the use of unmanned aerial vehicles by Hezbollah during the war in Lebanon in 2006 indicates such proliferation of new technology. Peter Singer illustrates these challenges by questioning the implications of the US fighting wars with hardware made in China and software made in India. ${ }^{48}$

Thomas Friedman's synthesis of the future as "hot, flat, and crowded,” reveals the combined trends of global warming, the rise of the middle classes, and rapid population growth. ${ }^{49}$ His analysis reveals a strong possibility that the future might bring a dangerous combination of geopolitical rivalry and environmental crisis. Likewise, the access to resources might pose a renewed emphasis on geography and geopolitics. For instance, the current tug-of-war over Arctic resources may turn out to be the most important territorial dispute of this century with severe consequences to the environment. ${ }^{50}$ Along with the comparative erosion of the US's hegemonic position emerges the menace of state confrontation reminding the persistent historic motives for war: "fear, honor, and interest."51

In 2025, warfare is expected to be characterized by the increasing importance of information; the evolution of irregular warfare capabilities; the prominence of the non-military 
aspects of warfare; and the expansion and escalation of conflicts beyond the traditional

battlefield. ${ }^{52}$ Additionally, the current emphasis on non-state threats and actors extends to future conflicts. There are authors who even dismiss decisive wars between major states, characterizing the future security environment as filled with minor conflicts. ${ }^{53}$ However, the main reason that major interstate wars are "enjoying an off-season” is that the imbalance of military power is so great towards the US that potential rivals avoid upsetting the superpower. ${ }^{54}$ Nevertheless, this assumption does not mean that adversaries will resign from competing with the US. It means that they will be more innovative when challenging US's hegemony. Hence, the next sections will discuss a possible answer to the research problem. A holistic approach encapsulated by the concept of URW.

\section{The Art and Science of Unrestricted Warfare}

The previous section discussed the drivers of future warfare and how they would interact with the American way of war to create opportunities for a future peer competitor. Having established the prowess of US's conventional military power, and the probability for a future conflict between the US and an emergent peer competitor, this section will seek to answer the following problem: What are the conceptual foundations, dynamics, and dilemmas of such a strategy? Answering this question should unveil the strengths and weaknesses of URW.

\section{Conceptual Foundations}

Sun Tzu asserted that, "To subdue the enemy without fighting is the acme of skill."55 However, the idealized vision of subduing the enemy without battle is not, according to Ian 
Johnston, the prevailing theme of the Chinese strategic culture. ${ }^{56}$ Conflict may actually be preferred on some occasions. It all depends on the priorities and objectives.

The conceptual foundations of URW strategy follow this principle of "absolute flexibility" or quan bian, where the "not fighting approach" is just one of the panoply of methods available. Also, the notion of quan bian lifts the political, military, or moral constraints that may hinder the strategic choices, allowing the selection of "any and all actions that will achieve one’s goals.”57

Establishing a simple but comprehensive definition of URW is the starting point for discussion. However, probing the literature indicates that trying to define URW may become a conceptual quagmire. Several scholars characterize future warfare as a mix of methods and actors, adding more complexity to the current warfare taxonomy. Arguments for Irregular Warfare, Unconventional Warfare, Fluid Conflicts, Fourth Generation Warfare, and Hybrid Warfare are scattered in the literature. ${ }^{58}$ Since URW is not a doctrinally defined term in the US, it has a pervasive definition, meaning different things to different people and organizations. Some relate this kind of conflict with the impact on American values, violating Western cultural sensitivities and norms. This view exposed by Ronald Luman relates URW to a conflict in which the enemy takes actions that cause shock and fear, offend, and even generate disbelief in the American mind. ${ }^{59}$ More commonly, URW has been identified as asymmetric warfare. ${ }^{60}$ However, the concept of URW is broader than just an asymmetry in military capabilities, reflecting rather an idiosyncrasy since it reveals an unorthodox approach or means of applying a capability, which doesn't follow the rules. ${ }^{61}$ Such strategy broadens the boundaries, instruments, and actors of war, making power projection more affordable, coercive, and lethal. This is particularly important to contemporary societies, deeply integrated and dependent on technology, making them very susceptible to idiosyncratic attacks. ${ }^{62}$ 
AU/ACSC/1172/AY09

According to its original proponents, Colonels Qiao Liang and Wang Xiangsui, URW employs “all means, including armed force or non-armed force, military and non-military, and lethal and non-lethal means to compel the enemy to accept one’s interests."63 This study borrows Liang and Xiangsui’s perspective, but seeks to complement their concept using contemporary lenses. Therefore, it aims to provide a working definition which reflects the unique characteristics and essence of the URW concept focusing the discussion on the perspective of a future peer competitor. This can be done by organizing the ideas of its original proponents with the strategy's framework of ways, means, and ends. In short, strategy aims to answer how to use power to achieve objectives. ${ }^{64}$ Hence, URW encompasses the use of unrestricted measures, applying all available instruments, to achieve limited objectives.

Considering all these arguments, this study will define URW as a holistic strategy which employs coherent and integrated multidimensional actions, synchronized in time and space, combining all available means, including military and civilian, violent and non-lethal force, targeting adversary’s wide-spectrum domains, aiming to affect the opponent's will and capabilities during times of real or perceived conflict. Clausewitz has warned us that war tends towards extremes and URW is the best example of pushing a combinatory game to the edges. ${ }^{65}$ It simultaneously changes the warfare concept and the role of the combatant. Informed by the URW definition and its strategic uniqueness, it's now time to probe and explain its dynamics and strategic principles, unveiling its strengths.

\section{Dynamics and Strategic Principles}

In order to understand the strengths of URW some fundamental questions need to be answered. Why fight and for whom? Where to fight? Who fights? What is targeted? What 
means and methods are used? Exploring these questions will unveil the URW strategic principles as a set of interrelated features such as the aims and allegiances of the belligerents; the battlefield ubiquity; the rise of super-empowered individuals; the expanded target sets; and the fluid operational methods and weapons.

Aims and Allegiance of the Belligerents. Although religion and culture will continue to be major sources of conflict, war will be primarily waged as a political event, with self-interest the ultimate motive. Within this framework, URW strategy emerges as a rational activity which seeks an advantage over a superior adversary. Therefore, instead of seeking unlimited objectives, the peer competitor's ultimate goal would be to constrain the US's response within a regional or global sphere of interest. Achieving such an end state would be facilitated if the US had to prepare against all possible attacks or operate simultaneously on several fronts, thus splitting its forces and increasing its vulnerability to attacks. Considering the rise of a peer competitor, the notion of "threat kingdom actor" expresses the most dangerous potential opponent, able to engage across the entire spectrum of conflict in time, space, intensity, and instruments of power. ${ }^{66}$ Robert Bunker shares this opinion, confirming that this innovative ability of matching the best threat with the most suitable means available, whilst wielding other than military methods, makes URW, as a nation-state grand strategy, such a formidable threat. ${ }^{67}$

Battlefield Ubiquity. Technology has enabled a double transformation in war's battlefield. It allowed both a vertical and lateral expansion. Until the twentieth century, the battlefield was confined. Then, airplanes allowed the military to circumvent the static battlefield adding a third dimension to the fight. However, information technologies moved the battlefield laterally, creating a technological space (the cyberspace), expanding into "non-physical” domains and allowing influence and disruption of the conventional space without occupying it. ${ }^{68}$ Current 
conflicts are showing an increasing tendency to expand the battlefields from the physical domain into informational, cognitive, and social domains, affecting politics, economics, culture, and people’s minds. In the future, nanotechnologies will augment the current bio-chemical capabilities, moving the battlefield into a microscopic arena. As seen before, the traditional American way of war seeks primarily a military victory on the battlefield. Conversely, the URW strategy aims to achieve victories beyond the military battlefield, striking at the heart of Western society’s values in order to shape public opinion and influence events. ${ }^{69}$ When adversaries camouflage within civilians, exposing them to casualties from air attacks, they exploit the effects of collateral damage through global media, seeking to gain support for their cause. ${ }^{70}$ Conflicts of this nature reveal the polymorphous and omnidirectional nature of future battlefields, where fighting will take place simultaneously in macroscopic, mesoscopic, and microscopic spheres. ${ }^{71}$

The Super-empowered Individual. Within the URW construct the military has lost the monopoly of force. This is not new, however the novelty resides in the fact that the boundaries between professional soldiers and non-combatants is becoming more diluted. Worst than that, military forces are ill suited to be successful in this new strategic arena because traditional military forces are not well prepared to engage beyond the military domain. ${ }^{72}$ In this new arena, the super-empowered individual, being a software engineer, scientist, a financier, or even suicide bomber, has the capability to affect and possibly disrupt a nation-state. The reach and scale of their strategic impact extends to all domains of human interaction. They are able to establish ties with other individuals, organizations, and states. These interest alliances are flux variables, rapidly emerging and dissolving, changing the face of the enemy. The leverage provided by their knowledge and anonymity improves their freedom of action and survival capability, making 
them high value assets in future conflicts. Hence, coordinating a force of super-empowered individuals, under specific commanders’ intent, will be the ultimate goal of a peer competitor.

Expanded Target Sets. Every strategy seeks to target the adversary's vulnerabilities. In a complex environment, such as American society, there are several weaknesses that are worth exploring. The interconnected economy, critical infrastructure, society, and media, all have vulnerabilities. The political decision-making process is complex and requires consensus. The limitations imposed by the laws of conflict hinder the application of military force. The need for international cooperation allows for lengthy debates obstructing effective and timely responses. The pervasive nature of the media transforms a tactical event into strategic effects. The impossibility of guaranteeing total security creates anxiety and uncertainty. This is the nature of a modern liberal democracy. ${ }^{73}$ Therefore, explicitly targeting civilians and supporting infrastructure, reflects the emphasis to destroy the Western state’s center of gravity: its liberal values. $^{74}$ Targeting critical infrastructures allows the disruption of quotidian activities, instilling fear in the population, and inflicting severe economic costs, both on the protection of key assets and on its reconstruction. ${ }^{75}$ Targeting living organisms, such as crops, cattle, and the people takes the fear threshold to whole new levels. Again, this is not new. History has shown the tendency to target civilians using punishment strategies in order to coerce a political change. ${ }^{76}$ However, the preferred instrument of power to inflict such harm has always been the military. On the contrary, URW leverages on the global interconnectedness and technological advances to maximize its effects over the population, mixing and matching military with non-military methods, prescribing a multidimensional approach using 'new concepts of weapons.'

Fluid Operational Methods and 'New Concepts of Weapons.' Most conflicts in history have been waged as a combination of methods of warfare, but the main effort occurred within 
the military domain. The following table encompasses some of the forms of warfare which are possible within the URW strategy (each form of warfare is described in Appendix 1).

Table 1. Examples of Unrestricted Warfare Methods

\begin{tabular}{|c|c|c|}
\hline Military & Trans-military & Non-military \\
\hline Atomic Warfare & Diplomatic Warfare & Financial Warfare \\
\hline Conventional Warfare & Network Warfare & Trade Warfare \\
\hline Bio-chemical Warfare & Intelligence Warfare & Resources Warfare \\
\hline Ecological Warfare & Psycological Warfare & Economic Aid Warfare \\
\hline Space Warfare & Smuggling Warfare & Regulatory Warfare \\
\hline Electronic Warfare & Drug Warfare & Media Warfare \\
\hline Guerrilla Warfare & & Ideological Warfare \\
\hline Terrorist Warfare & & \\
\hline
\end{tabular}

Source: Liang, Qiao and Wang Xiangsui. Unrestricted Warfare, 38-43,123.

Although most forms of warfare have existed for centuries, due to global interconnectedness and technological advances, their impact over society has exponentially grown. Also, the major difference lies at the intellectual level. Instead of simply combining and adding forms of warfare, URW strategy aims for simultaneity in order to achieve a final outcome which is greater than the sum of its parts. This requires holistic thinking which is cross-level (tactical, operational, strategic); cross-domain (air, land, maritime, space, and cyberspace); and crossdimension (military, trans-military, and non-military). The principle of combination or addition seeks to mix and match different actors, ways, means, and stages in order to achieve limited objectives. ${ }^{77}$ Combining national, international, non-state organizations, and even individual actors, provides the essential leverage to achieve the national security objectives. 
Thinking synergistically also applies to a diverse array of weapons. It's expressed by the dichotomy between "making the weapons that fit the fight," and "fight the fight that fits the weapons. ${ }^{78}$ While the former idea relies on technological advances, and reflects the traditional way of warfare where the superior fights the inferior, the latter allows the mix and match of capabilities, seeking the optimum tactics for the weapons one has. ${ }^{79}$ Inseparable from the previous dichotomy are the contradictory qualities of 'weapons of new concepts' and 'new concepts of weapons. ${ }^{80}$ The former are the hallmark of the American way of war, and have increased precision and lethality, but are expensive and can only be used by professional soldiers on specific battlefields. The latter concept "views as weapons all means which transcend the military realm but which can still be used in combat operations" ${ }^{81}$ They are more affordable, readily available, and have wider disrupting effects, ranging from stock market crashes, computer viruses, and rumors or scandals that affect currency exchange rates. ${ }^{82}$ The epitome of such concept was revealed during the 9/11 attacks, where non-military means and ways were employed to achieve political objectives. Thus, this perspective reveals the shift from a technology-centric mindset to the importance of intellect and strategy.

The trend of technological diffusion, the increasing practice of outsourcing, and the reliance on commercial off-the-shelf products, all facilitate the creation and employment of 'new concepts of weapons. ${ }^{83}$ The future availability and affordability of dual use technologies, such as directed energy, biotechnology, and nanotechnology, will provide additional means to impose fear and uncertainty. A parallelism may be found between such 'new concept of weapons' and some Chinese capabilities referred to as 'Assassin's Mace Programs.' These weapons or tactics are viewed as a 'silver bullet' which would render any adversary response useless. In the end, they will function as psychological instruments to create more uncertainty and anxiety. For 
example, some of the non-military methods may produce strategic effects similar to the use of nuclear weapons but without the political risks of crossing the nuclear threshold. ${ }^{84}$

Edwin Lowe condenses the URW perspective about conflict in one word: "totality."85 This is the most distinguishable strength of URW because, instead of mobilizing all society to support the military effort, it expands warfare beyond the military domain. Therefore, its holistic and synergistic view of conflict, as a function of statecraft, contrasts with the compartmentalized and categorized, scientific approach of the West. ${ }^{86}$ Nonetheless, there are several challenges which may hinder the effectiveness of the URW strategy.

\section{From Promise to Reality}

The translation of a strategic concept to reality can unveil possible weaknesses and dilemmas. Therefore, it is important to assess the strategy suitability (will it achieve the effects desired?), feasibility (can the actions be accomplished by the means available?), and acceptability (are the methods, resources, and the effects justifiable?), to determine the validity and risk of such a strategy. ${ }^{87}$

At the conceptual level, the proliferation of different perspectives about URW doesn't facilitate its understanding, thus making its operationalization a complex task. Additionally, the negative connotation of URW, as opposing the rules of war, renders it difficult to translate into doctrine and execution. Perhaps this could be the reason why some authors address the URW concept under a different name, in an attempt to make it more appealing as a strategy. ${ }^{88}$ Although it has been identified as one of the four current Chinese schools of military thought, there is no express indication that an URW strategy is being employed in a holistic manner or as an official doctrine by any nation-state. ${ }^{89}$ Yet, there are signs of embryonic stages of URW 
strategy, reflecting scattered actions and probing efforts in several domains. For example, after the collision of a US surveillance plane and a Chinese fighter plane, in 2001, several hackers defaced dozens of US military Web sites. ${ }^{90}$ Another URW-like event links pro-Russian computer hackers with cyber attacks against Estonia, Lithuania, and Georgia through incidents

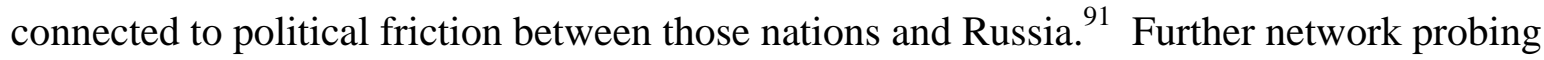
activities cannot be officially attributed to a nation, but there are some suspicions that they can be traced back to China. ${ }^{92}$ Other incidents were also linked to China, acknowledging the development of disrupt technologies such as anti-satellite capabilities and cyber warfare. ${ }^{93}$

These examples portray URW, as mentioned by Steven Metz, as a 'proto-concept' rather than a mature one. ${ }^{94}$ Nonetheless, he acknowledges the fact that the URW approach posits a true strategic revolution because it provides a conceptual approach that is being partially employed against the US, providing valuable lessons to future peer competitor strategies.

The unlimited nature of battlefields and the expertise required to be effective on those domains pose additional constraints on the strategist. Although in the past this was not strange to the military strategist, URW stretches the operational art to new levels, domains, and dimensions, challenging the orthodoxy of Western thinkers. Therefore, orchestrating an effective holistic strategy will shift the emphasis from science to the art of war, creating additional problems regarding the education and training of future professional warriors.

The premises of URW, traceable from ancient Chinese experience, require secrecy, surprise, denial, and deception in order to create maximum impact. Although secrecy has always been inherent to warfare preparations, URW raises this principle to the grand strategic level, allowing its proponent to wage operations against an adversary without their awareness that a conflict is underway, thus limiting their responses. Therefore, secrecy is vital for the success of a long-term 
strategy. Moreover, concealing strategic intentions protects a country from the eventuality of a preventive strike. However, this purposeful uncertainty of strategic intentions conflicts with the demands of transparency and the free flow of information within the integrated global economy. ${ }^{95}$ Hence, the potential for others to misunderstand such strategic intentions will increase. Due to the target's nature, the methods employed, and the impact of its effects, those actions can be viewed as an act of war. ${ }^{96}$

Likewise, peer competitors may overestimate the promises of URW compelling them to engage in offensive operations, misjudging the effects of their decisions on the security perceptions and responses of the adversary. ${ }^{97}$ An effective strategy must consider war as a duel, thus taking into account the response of the adversary. For example, the underestimation about the US resolve to endure casualties may also contribute to a conflict escalation, leading to an American 'unrestricted' response even risking the crossing of the nuclear threshold. Conversely, 9/11 has raised the US's awareness about its vulnerabilities, which in turn has increased the risks for an adversary willing to wage URW.

The previous examples highlight the complexity of employing a holistic URW strategy. Determining which measures to apply, and above all, what effects will be produced, is a difficult task. This would require a whole of government approach, making it hard to synchronize. This ability to increase chaos beyond the military domain raises problems regarding the decisionmaking process. Since the dawn of time man has tried to decrease the fog and friction of conflict, searching for certainty in warfare. However, forecasting strategic effects, in particular the second and third order effects is impossible. ${ }^{98}$ That would require an unachievable level of predictability and knowledge of the enemy, and the reactions of complex systems. Hence, this will never be a perfect science. ${ }^{99}$ 
The discussion has submitted the URW concept to a litmus test revealing several challenges in its suitability, acceptability, and feasibility. Within a peer competitor framework, having something at stake, such as territory, population or economic interests, coupled with the possibility of conflict escalation, and the complexity of orchestrating operations, may prevent the holistic employment of URW. However, from an adversary's perspective, URW as a risk-taking strategy presents an effective approach because it provides the means and ways to target the US's vulnerabilities. Although in embryonic stages and charged with a negative connotation, it serves its ends as an effective strategy to fight wars in a world of risk societies. Further, if applied in a holistic manner, considering limited objectives, its strengths and strategic effects could surmount its weaknesses and challenges. Finally, the availability of means and multidimensional methods, although with complex orchestration, provide a framework to unleash the power of URW. Considering the opportunities, strengths, and dilemmas of URW it's now possible to foresee, more clearly, some of its implications for the future of warfare.

\section{Strategic Implications of Unrestricted Warfare}

URW cannot provide the only answer to wage future warfare. Nevertheless, it provides a framework and capability for a peer competitor to confront the US in a holistic manner. By exploring the strategic implications of URW it is possible to exercise 'beyond-the-box' thinking about future warfare. Although these implications are intertwined, this study will concentrate the analysis under a template of legal and moral dilemmas, civilianization of war, and risk society challenges. This analysis will support the need for a change in mindset.

\section{Legal and Moral Dilemmas}


The legal framework that oversees warfare has increasingly narrowed the acceptable measures with which to wield the military instrument of national power. The Geneva and Haig Conventions, the United Nations Charter and Resolutions, and many domestic laws, all bound modern warfare. Although war has become a less recurrent political method to solve disputes, it has become a more complex endeavor, highly restricted by Rules of Engagement and the increasing legal scrutiny of targets in order to minimize collateral damage. Public and international support depends on the ability to win wars while reducing casualties. This trend in modern warfare indicates a possible transformation of war into the "continuation of law by other means.”100 However, due to its multidimensional nature URW challenges this legal construct, raising difficult questions such as what can be regarded as an act of war in a non-military domain? For example, would trade warfare or media warfare be considered an act of war? How about overloading a server in order to cause it to shutdown? On the other hand, will international law be discarded by a state employing URW? Will future war be fought in a legal vacuum or will the international system adapt? In the long run, the conduct of war without conventions is impossible, and thus a new framework will emerge to define who is allowed to kill whom, for what ends, under what circumstances, and by what means. ${ }^{101}$ History is fertile on such examples. The twentieth century may have forbidden soldiers to loot and rape, but allowed the destruction of whole cities from the air. ${ }^{102}$

\section{Civilianization of War}

Can the nation-state adjust to the prospect of URW? As seen before, state actors no longer have a monopoly over the catastrophic use of violence. The civilianization of warfare is a natural consequence of URW, and the democratization of violence allows virtually everyone to 
join the fight with ever growing capabilities and effects. Shifting the fight to areas other than military battlefields will empower a new kind of warrior. This will pose additional constraints on the nation-state in order to command and control such individuals (hackers, financial speculators, or multinational companies). Additionally, the use of Private Military Companies (PMC) provides further leverage for a state to impose its will. ${ }^{103}$ The innovative employment of PMCs to offset the legal constraints on the use of force, allows the sponsor state to fulfill its interests without being accountable for the actions of such armed companies. ${ }^{104}$ The use of force by a nation-state is well regulated. If a country decides to deploy armed forces to provide Foreign Internal Defense to a third country, it will face some scrutiny from the international community. However, the same doesn't apply to a PMC. In fact, when a Chinese company signed a contract to supply defense contractors to Angola in exchange for an oil agreement, there was no international repercussion. ${ }^{105}$ Perhaps, this reflects the increasing trend of state use of PMCs in modern conflicts, Iraq being one of the highest exponents. ${ }^{106}$ Using private and multinational corporations as instruments of warfare seems to indicate an increasing outsourcing of warfare. This trend will likely grow as a direct result of the expansion of the battlefields. Hence, PMCs may function both as an URW enabler as well as 'less regulated' instruments to counter URW adversaries. Although states will continue to be the basis of international order, these tendencies will increase the blurring between war and crime as well as the difference between armed forces and civilians. Hence, as Van Creveld has observed, "often, crime will be disguised as war, whereas in other cases war itself will be treated as if waging it were a crime."107

\section{Living in a Risk Society}


The perception that technology and globalization have transformed the magnitude of risks which affect contemporary societies is a central theme of social studies. ${ }^{108}$ From global warming to the way to wage war, advanced societies strive to anticipate future catastrophes which in turn influence their decision-making process. Given the diverse areas of conflict encapsulated by URW, then the challenges facing the technology community in countering such wide array of methods and weapons are immense. ${ }^{109}$ The introduction of new technologies in warfare, such as genomics and nanotechnology, will further diversify the methods of attack, increasing the possibility for bioviolence. Barry Kellman alerts that the destruction of living organisms, unlike nuclear or traditional warfare, can be executed quietly and anonymously, making its prevention even more challenging. ${ }^{110}$ Therefore, preventing adversaries from sowing fear and uncertainty in a complex society is a daunting task. The number of casualties from the $9 / 11$ attacks were relatively low if compared with the effects of fear and uncertainty in public opinion that they motivated. Likewise, attacking critical infrastructure such as an airport or a water supply system might cause reduced casualties. However, the prospect of insecurity, distrust, and uncertainty would generate ripple effects which could spread to other quotidian activities. The panic caused by the employment of a weapon can be as harmful as the physical destruction. This effect of psychological nullification, as Max Boot describes it, is likely to diminish upon future engagements of the same weapon. ${ }^{111}$ Nonetheless, URW induces an emergence of a new paradox. While the West continues to narrow its view of warfare's acceptable parameters, the adversary amplifies the concept of total war. ${ }^{112}$

Since URW challenges the defense, and preventive measures are unable to protect from every imaginable risk, then the answer is learning to live with risks. Moreover, risk is a scenario followed by a strategy on how to prevent it. ${ }^{113}$ However, quantifying risks has become 
extremely difficult, making it harder to rally public support for the use of military force. ${ }^{114}$ Therefore, the main implication facing the US is how to psychologically prepare for and actively counter URW. On the other hand, the increasing need for security may eventually lead to the willingness of future societies to trade their civil liberties for their physical and psychological protection. ${ }^{115}$ In the end, successfully countering URW will require the American people to perceive such risks as exceptional events that don't require extensive changes in their way of living. ${ }^{116}$ Achieving this threshold requires increasing the US's resilience to URW. Therefore, reducing the cascading effects of a target's disruption would provide a degree of deterrence against possible attacks. However, it's impossible to achieve complete security. First, there aren’t enough resources to protect all the critical targets. Second, the ambiguity of the threat makes it hard to locate, monitor, and respond. For example, there is a wide-spread belief that intelligence gathering operations against the US are being conducted. These state-sponsored probing activities engage in political, military, industrial, economic, and technical espionage. ${ }^{117}$ However, the state's responsibility for individual actions is often disowned. According to McAffee, the world's largest dedicated security technology company, there is a considerable misdirection as to the origins of the cyber attacks. ${ }^{118}$ Many cyber attacks are just as likely to originate in the same city as the target. Those obfuscation activities render it difficult to attribute the responsibility for the origin and sponsor of the attacks. Hence, although technology may provide additional surveillance and tracking capabilities, the ambiguity of URW actions hinders deterrence, retaliation, and proportional response.

Exacerbating this trend is the perception of what may be an indirect attack by a major trading partner. Robert Bunker highlights this ‘perceptional trauma’ which causes immense detrimental effects on US views and analysis about China's foreign policy. ${ }^{119}$ Although there are 
always alternative and more benign explanations, Max Boot confirms this uncertainty about the strategic intentions which makes every adversary’s action a possible indication that URW strategy is being implemented. ${ }^{120}$

The alignment of the previous implications exposes the fundamental strategic challenge of URW: the need for a shift of mindset in order to understand that the main strategic differences towards warfare are cultural. Hence, viewing the adversary under the Industrial Age’s lens, purely in technological terms or number of weapon systems, misses the strengths of URW. The adversary does not need to destroy the US’s military forces in order to win. It can achieve victory if able to impose sufficient political and social constraints. Therefore, understanding warfare as a holistic endeavor is the essential first step. Integrating national power beyond the military domain appears to be the logical next step. Engaging the society in a collective effort and providing a new institutional framework which increases the resilience to URW actions could be a possible answer. But the main question still remains: how to do that? The next section, as the corollary of this study, provides some suggestions on how to address this problem.

\section{Recommendations}

By now, the reader may be questioning how to craft a response to an indirect aggression in a globalized and technologically advanced world. This is not a simple task. Quantifying the military threat is fairly easy, but measuring an adversary’s intent and capability to employ URW is completely different because it spans all instruments of power, hard and soft. The previous analysis revealed some factors that may hinder an effective US response. First, there are legal constraints such as the adherence to the Laws of Armed Conflict and Just War doctrine. ${ }^{121}$ Second, the need for popular support will limit the scope of the response, especially if there are 
no vital interests at stake and if the response involves the expenditure of blood and treasure. Furthermore, at the political level, the current focus on combating terrorism and the dire global economic situation deflect political attention from a holistic peer competitor.

Therefore, within such constraints but considering the unique attributes and the strategic implications of the URW concept, this study highlights the importance of the coherent integration of the US's national security strategy. The size, complexity, responsibilities, and resource competition of the American strategic decision-making process are beyond the scope of this study. Nonetheless, this analysis has distilled several recommendations that should be incorporated in the US's grand strategy. This involves a three step approach based on renewed strategic thought, a holistic-agency approach, and a people-centric perspective.

The first recommendation concerns the need for renewed strategic thought. This perspective is informed with the mindset that, "With a good strategy, even the weak can succeed; with a weak strategy, even the strong will struggle.”122 Therefore, expanding the strategic perspective beyond the war on terrorism and acknowledging other threats will be the first step. Concentrating too much time, attention, resources, and engagement into one particular area of the conflict spectrum exposes vulnerabilities in other areas, such as the rise of future peer competitors. $^{123}$ URW theory has shown the importance of the non-military dimension in warfare, thus requiring a shift of the traditional American approach to war.

The second recommendation regards institutional culture. The prospect of URW demands a 'purposeful adaptation' of the interagency system. ${ }^{124}$ Such adaptation normally happens as the result of tragic events with impact to national security. Although change is a phased approach, starting during peacetime, it requires a major violent event to decisively change the way to do business. $^{125}$ That was the case for the creation of the Department of Homeland Security, along 
with a myriad of strategic guidance. Currently, the expansion of warfare beyond the military domain creates additional demands for a holistic approach to national strategy. That includes the national instruments of power as well as the influence over international organizations.

The perception that the US lacked a coherent grand strategy regarding its counter terrorism action after 9/11 is well exposed in the literature. ${ }^{126}$ Although American power and influence is pervasive and multidimensional, the challenge of strategic integration, that is, bringing the instruments of power into coherent effectiveness through the use of the interagency process, still remains. ${ }^{127}$ Several factors may explain this symptom. Historic reliance on the military tool as the strategic solution to conflicts has channelized resources into the Department of Defense. ${ }^{128}$ Additionally, the lack of unity of command throughout the interagency process has compounded the problem. ${ }^{129}$ Furthermore, the blurring of domains and the effects of non-military actions add complexity to the coordination of a coherent response. Finally, a holistic capability requires an integrated national strategic guidance. Yet, the proliferation of strategic guidance along with the increasing complexity of unaligned processes and ad hoc solutions, hinder the integration and synchronization of efforts. ${ }^{130}$ However, in defense of the status quo it must be said that, although concentration of power and authority may work well during time of crisis, during peace time this concentration creates a tension between government institutions and the society. Moreover, even though centralization of power may be the hallmark of an authoritarian state, it goes against the very nature of a liberal democracy like the US. Therefore, the US's society may be willing to accept some inefficiency in order to avoid a concentration of power in one government institution.

Nonetheless, the inability to think strategically beyond the West's concepts of warfare will be a major disadvantage for the US. The main focus should not be the existing threats, but the 
emerging ones. That's when strategic planning comes into play. Crafting a response which is enforced and sustained by all national security actors is the main purpose. After all, the dilemma in strategic affairs is always to balance the capabilities with the short and long-term requirements. This means that the first step should be to provide the strategic guidance to allow the integration of the instruments of power and influence, creating an important security multiplier. ${ }^{131}$ Such efforts must address both military and civilian organizations, national and international institutions, public and private. The release of a new National Security Strategy along with a new Quadrennial Defense Review in 2009 will constitute valuable opportunities to address the growing debate concerning the reform of the US government's national security system. ${ }^{132}$ Moreover, considering the previous discussion and the need to extend the strategic vision beyond the military domain, the US's grand strategy should include the implementation of a Quadrennial National Security Review. This tool would serve the purpose of aligning the efforts of all instruments of power, providing a common language and perspective about the future challenges.

The final recommendation concerns the need to move from a technology-centric perspective to a people-centric approach based on education. Strategic education will have two main functions. First, educate the strategist about different strategic cultures in order to promote the understanding of the cultural behaviors and anticipate opportunities and motives for action. Second, the education of the national security actors should focus on their ability to manage uncertainty, ambiguity, and risk in order to cope with the complex, but fundamental, holistic interagency approach. Improving the non-military pillar of national power is one of the lessons learned from current conflicts which should be helpful when dealing with URW threats. The need for unity of effort and command provides the motive for change. However, this requires an 
effective interagency approach as well as a cross-manning of such agencies. Hence, education by itself is not enough. Changing institutional culture is a phased incremental phenomenon. ${ }^{133}$ The acceptance of a new idea depends on the recognition of its merits, sometimes only possible after the perceived failure of old ways of doing business. Further acceptance can be achieved if influential opinion makers sponsor this new idea. Adopting new frameworks requires the support of the civilian and military leadership and the establishment of tangible incentives for change. Those incentives need to reward desirable behaviors such as cross-agency collaboration and service, thus promoting an interagency ethos. The process can be expedited by institutionalizing change through mandate, such as the Goldwater-Nichols Act of 1986, but this time expanding beyond the military domain. This legislative framework would encourage the development of national security professionals, military and civilians, "whose purpose would be to staff key positions in the national security structures."134 Understanding the diverse cultures, functions, capabilities, and limitations of the actors in the interagency process will promote increased unity of effort and a more effective orchestration of the instruments of national power.

Future warfare will increase the need for creative strategic thinking. Developing a broad strategic understanding of the military role, but above all, understanding the importance of a holistic approach to war is something that the military leaders of tomorrow cannot afford to miss. ${ }^{135}$ Using the past as a prologue, it's possible to envision a preeminent future where success is predicted by "those who anticipate the changes in the character of war, not upon those who wait to adapt themselves after the change occurs.”136

\section{Conclusion}


As this study has tried to demonstrate, there is more to war than warfare. ${ }^{137}$ War, as politic object, expresses a state of conflict, which encompasses the use of all instruments of national power, where military power is just one available tool. Second, viewing warfare from its binary perspective, objective and subjective, it is possible to envision a historical trend about warfare. ${ }^{138}$ The objective nature of warfare, which includes violence, friction, danger, exertion, chance, and uncertainty, is unchangeable. Conversely, the subjective character, its grammar, such as doctrine, technology, or people, changes along with the context. Finally, every age has its own form of warfare, its own limiting conditions, and preconceptions. ${ }^{139}$ Confronting this Western framework with URW unveils the need to start learning the new grammar of future warfare.

Globalization, the technological interconnectedness of societies, and America’s military prowess have created the opportunity and necessity for future peer competitors to exploit URW strategies. Although there is no single, all encompassing warfare theory that can be applicable to all possible futures, viewing conflict in a holistic manner provides windows of vulnerability that can be exploited by a future US challenger. URW renews the emphasis on the art of war and its decisive element, the human factor. Technology is just another enabler, and military power just one instrument in a multidimensional domain. The analysis about the dynamics and principles of URW has shown its strengths, but also its challenges. Although difficult to apply in a holistic manner, the evidence suggests that the URW concepts are widely understood and applied.

This study has identified several challenges to US national security. They all reveal the imperative for a broader strategic view about URW, and the ‘purposeful adaptation’ of the interagency process along with the education of the national security practitioners. Rather than providing definite answers, this study has tried to question the status quo and expand the discussion 'beyond-the-box' of conventional military thinking about warfare. By doing this it 
AU/ACSC/1172/AY09

aimed to promote future reflections about URW. Many questions are left unanswered thus requiring further investigation. For example, what constitutes a legitimate target? What should be the criteria to determine a response? Further, what are the indications of an impending attack? If society does not learn to live with risks, then the lack of answers only increases the probability of a state adopting preventive response strategies.

In the future, it is the ability to impose will, not the level of violence, which will eventually lead to a better peace. The future journey is a complex endeavor indeed; however, so are the consequences of Unrestricted Warfare. 


\section{Appendix 1}

\section{Unrestricted Warfare Methods}

The methods of warfare envisioned by the original URW proponents include a variety of forms of coercion which expands beyond the traditional military domain. ${ }^{140}$ While using this framework as a reference, this appendix will draw evidence from other authors seeking to gather additional support about possible challenges to US's national security. The list is not allinclusive and the boundaries between each method are not perfectly defined. Although their strength lies on the synergistic employment of a combination of methods, the individual description of these methods along with examples of its implementation will enhance the understanding of URW strategy.

\section{Military Dimension}

Atomic Warfare. The proliferation of states seeking nuclear weapons as a form of deterrence and preeminence in regional and global spheres will create a renovated nuclear arms race. For example, the prospect of a nuclear Iran increases the regional security dilemma possibly leading to further nuclear escalation. History has shown that nuclear deterrence didn't preclude the existence of wars. However, it has tended to limit the expansion of conflicts. Nonetheless, the diffusion of technology and expertise indicates the possibility of expansion of the nuclear club with significant geopolitical changes. In 2008, eight declared nuclear weapon states possessed 10,200 nuclear weapons. ${ }^{141}$ Further questions are raised about the ability of weak states to control and secure their nuclear arsenals. ${ }^{142}$

Conventional Warfare. This method reflects the application of traditional military capabilities primarily against the adversary's armed forces. The trend towards precision, lethality, and speed allows tailored application of combat power. The perspective that modern conventional warfare is declining between advanced societies results from its effectiveness. Additionally, the increasing costs of modern conventional armed forces when compared with other methods along with nuclear deterrence may contribute to the decreasing effect. Moreover, the scale and quantity of resources involved in conventional warfare will tend to decrease due to the sophistication and complexity of operations. ${ }^{143}$ Finally, the historical examples of combat effectiveness of conventional forces against other forms of fighting may shift the emphasis of nation-states towards unconventional methods.

Bio-chemical Warfare. This method includes the employment of living organisms or chemical substances to kill or incapacitate. Although the Geneva Convention prohibits a nationstate from using bio-chemical weapons it is not enough to prevent against its hostile use. Developing an infectious agent and then dispersing it in the adversary's territory has the potential to cause a social and economical catastrophe. The examples of anthrax released in Washington DC in 2001 or the use of chlorine by insurgents in Iraq in 2007 increases the requirement for biocontainment and bio-security. ${ }^{144}$

Ecological Warfare. Engaging in warfare has always had ecological implications. Moreover, it is difficult to distinguish the difference between an accident, the manipulation of a 
disaster, or a deliberate action which may produce an ecological catastrophe. Burning a forest, causing an oil field fire, or contaminating fresh water reservoirs, may physically harm and inflict serious economic and ecological damages on a country. Additionally, the introduction of genetically altered species into different areas may cause ecosystems to collapse. Several examples of ecological warfare can be found in history. The use of herbicides in Vietnam, the burning of oil wells in Kuwait, the deliberate release of oil into the Persian Gulf, and the use of radioactive materials all have produced long-term deleterious effects that are difficult to quantify. In the future, being able to influence natural phenomena such as earthquakes, precipitation patterns, or sea level height may provide further methods to affect the adversary.

Space Warfare. Until recently, access to space has been restricted to a very few. However, the availability and affordability of commercial technologies and the advent of the internet have allowed the diffusion of space capabilities. Satellite imagery, communications, global precision navigation, and other services, act as capability multipliers providing additional leverage to civilians and military professionals. Besides additional intelligence and weapons accuracy, these space capabilities coupled with low-end computers and cell phones, allow any adversary to establish a robust command, control, and communication infrastructure which is difficult to counter. $^{145}$ Therefore, an emerging peer competitor will attempt to deny US's access to space, severely crippling the effectiveness of military and civilian operations.

Electronic Warfare. According with US doctrine, electronic warfare includes the military actions involving the use of electromagnetic and directed energy to control the electromagnetic spectrum or to attack the enemy. ${ }^{146}$ Military operations are increasingly dependent on the use of information systems and rely on the free access to the cyberspace. While it is impossible to achieve supremacy in the cyberspace domain there is a strategic requirement to deny the adversary's freedom of action in such domain. Therefore, it is necessary to integrate electronic warfare actions with computer network operations in a broader perspective of Information Operations. However, other nations have different perspectives about the use of the electromagnetic spectrum. Russia and China are some of the countries which are developing innovative forms to challenge US information superiority. ${ }^{147}$

Guerrilla Warfare. One of the oldest forms of asymmetrical warfare is doctrinally defined as military and paramilitary operations conducted in enemy-held or hostile territory by irregular, predominantly indigenous forces. ${ }^{148}$ In addition, the availability of information technology and global media allows modern guerrillas to achieve strategic effects. Likewise, global interconnectedness offers the capability to establish international networks and decentralized structures. The insurgency movement in Iraq and Afghanistan translates the nature of this method of warfare.

Terrorist Warfare. Combining the use of 'new concepts of weapons' with traditional terrorism causes the emergence of a new terror era, pushing the fear threshold to new levels. Such examples include the use of weapons of mass destruction, like dirty bombs or biological elements. However, similar damage may be inflicted by attacking information systems, causing the disruption of critical infrastructures such as nuclear power plants or air traffic services. The examples of the 9/11, the anthrax attack in 2001, and the Sarin gas attacks in Tokyo's subway in 1995 emulate this new kind of terrorist warfare. 


\section{Trans-military Dimension}

Diplomatic Warfare. In a predicted resource scarce and multipolar world, the capability to establish a network of regional and global alliances is essential to seize national interests. This is the traditional 'soft' instrument of power that every state wields in the international system. While the Soviets tried to control proxies during the Cold War, nowadays China provides the proxies with resources to be used as they see fit. ${ }^{149}$ Additionally, the creation of large regional organizations such as the European Union (EU), the Association of Southeast Asian Nations (ASEAN) or the North Atlantic Treaty Organization (NATO) allows concerted decisions which leverage the power of a single country. As an example of this transformational power consider the conditions imposed by NATO or the EU on states wanting to become new members of these alliances.

Network Warfare. This research has identified the importance of targeting the information systems and critical civilian infrastructures as an URW method to challenge the US. Besides the network attacks aiming to probe, disrupt, or deny services, stealing vital information such as intellectual property has severe consequences and economic impact. According to McAffee, in 2008, surveyed companies lost more than $\$ 559$ million worth of intellectual property. ${ }^{150}$ Based on those findings, McAfee estimates that the total global damage from data loss was more than $\$ 1$ trillion. ${ }^{151}$ Considering the global economic crisis along with the pressures to reduce spending and staffing, it is possible to foresee additional opportunities for cybercriminals to create a "perfect information security storm." 152 The emergence of peer competitors will create additional pressures to 'appropriate' intellectual property in order to maintain economic growth. ${ }^{153}$

Intelligence Warfare. The quest for perfect intelligence doesn't guarantee success in war or complete security in peace time. Being able to interpret and timely act upon the available intelligence is much more effective. However, intelligence can be contradictory, partial, secretive, overly abundant, and sometimes commonly misinterpreted. The examples of 9/11, the hunt for Iraq's weapons of mass destruction or the search for Bin Laden expose the limitations of intelligence. The advent of open source intelligence (from which the internet is the main source) provides an asymmetrical intelligence warfare capability to any competitor. Examples of such open source intelligence range from tips on how to construct improvised explosives devices, to satellite views of the target area available in Google Earth, or the training provided in chat rooms. This capability of information sharing, collaboration, and networking is one of the fundamental challenges for the intelligence community.

Psychological Warfare. Using information as propaganda to influence the adversary's decision making process is a basic instrument of warfare. It can be used as a coercive instrument which affects their will to fight. Recent conflicts in Iraq and Gaza have shown the importance of manipulating the adversary's minds. Russia and China are also exploring nontraditional, asymmetric approaches, respectively referred as 'psychotronic war' and 'new concept weapons. ${ }^{154}$ Their efforts are to utilize psychological operations to control the mind and affect the nervous system, upsetting human data-processing capabilities. 
Smuggling Warfare. The use of illegal and counterfeit products and the establishment of a parallel underground economy impair the adversary's traditional economy. In some nations, the volume of black market commerce exceeds the value of the traditional economy. Additionally, the fact that several states and organizations are trying to illegally acquire US military technology, if successful, allows potential adversaries to undermine the US's technological advantage and national security. ${ }^{155}$

Drug Warfare. Illegal drug production and trafficking supports organized political violence and challenges international stability. ${ }^{156}$ This method provides a huge influx of funds to sustain violent individuals, organizations, and states. On the other hand, it affects the sustainability of the target state's society, especially amongst youth, promoting crime escalation and in most severe cases directly affecting the political stability of the country. Furthermore, it drains resources from the target state towards fighting drug production and trade routes. Afghanistan, Mexico, and Colombia provide some of the examples of the domestic, regional, and global instability of drug warfare.

\section{Non-military Dimension}

Financial Warfare. In a networked economic environment the flow of electronic money can be disrupted causing serious damages to the economy. Financial warfare has become a 'hyperstrategic' weapon because is easily manipulated, allows concealed actions, and it's highly destructive. ${ }^{157}$ Moreover, it can be employed in a more targeted fashion, either by countries or super-empowered individuals. This strategy has been increasingly used by the US to punish and shape behaviors. ${ }^{158}$ Additionally, individuals sometimes seek to obtain maximum profit, such as the currency manipulation by an international financier or hackers trying to breach banking accounts. The financial system, which relies on massive transactions of money and credit, is highly dependent on confidence and trust. Therefore, the disruption of the financial foundations (i.e. the network in which the transactions heavily rely upon), may severely damage the system effectiveness, possibly collapsing the monetary transactions of a country and spreading severe economic and political consequences. ${ }^{159}$ Paul Bracken envisions financial warfare in an escalation framework. ${ }^{160}$ The process begins initially targeting individuals and companies by seizing their assets and then, expanding the measures to society, forcing a change of political behavior. Considering the US's vulnerabilities, although defensive measures are being put in place to protect the networks, there are several interdependencies which can be targeted with severe consequences to the operation of the financial systems. For example, the dependency on electrical and communication grids makes them a profitable target. ${ }^{161}$

Trade Warfare. This method includes all the legal tools which can impose domestic and international trade restrictions. Using sanctions, embargoes, trading cartels, or tariff barriers allows a country, or a group of nations, to cripple the targeted state by restricting goods, from oil to critical wartime technologies, or by imposing limitations to its exports. This instrument can damage the economy of the target state if the state is heavily dependent on these products and if there is no alternative methods to obtain such resources. In reality, the impact of such measures is often reduced due to the lack of restriction enforcement capabilities and also the country's resilience and innovative work around solutions. Moreover, the suffering is mostly imposed on the population and can sometimes backfire and unite them against the aggressor. 
Resources Warfare. The resulting pressure from economic and population growth will affect how states procure and secure energy, food, and water resources. The dependency on oil, either as a consumer or as a producer, will continue to shape global geopolitics creating additional flashpoints for conflict. While today 600 million people from 21 countries are classified as cropland or freshwater scarce, by 2025 that number is projected to double. ${ }^{162}$ The efforts to secure energy resources led China to establish a network of alliances either by providing economic aid or by directly acquiring companies in several African and South American states. Moreover, the concerns for maritime security are prompting China and India to buildup naval capabilities. ${ }^{163}$

Economic Aid Warfare. International aid can be employed as an instrument to induce and shape an adversary's behavior. It can involve simple humanitarian help or more extensive financial bailout packages. For example, as the biggest foreign holder of US government debt, China may leverage its position to constrain the behavior of the US. The economic leverage can be used also to limit the US's access to strategic regions. For example, in 2009 Kyrgyzstan announced that it would cancel the US lease of an air base after Russia agreed to provide Kyrgyzstan $\$ 2$ billion in loans and \$150 million in financial aid. ${ }^{164}$

Regulatory Warfare. The overall objective is to create a favorable legal framework which supports national interests. For example, China has attempted to shape international opinion regarding the interpretation of the United Nations Convention on the Law of the Sea, defending an increased sovereign authority out to the 200 nautical mile Exclusive Economic Zone, the airspace above it, and possibly even outer space. ${ }^{165}$ Likewise, democratic states are constrained by a variety of laws, particularly regarding human rights, which can be used by other states or organizations to improve their combat effectiveness.

Media Warfare. The advent of the Internet and global media allows any contender to influence perceptions and shape outcomes in order to obtain domestic and international support for their cause. In the midst of an information tsunami it is often difficult to determine the credibility of an information source. Multiple sources with different ideological, strategic, and commercial agendas increase the difficulty of operating within this environment. Using words and images as weapons, every competitor relies on the media to disseminate massive disinformation. Images and contents are manipulated, sometimes even fabricated in order to cause the maximum effect. Once they are released it is difficult to correct the initial public perception. For example, the 2006 conflict between Israel and Hezbollah highlighted the importance of media manipulation. During several CNN reports in Lebanon, Hezbollah maintained constant supervision of reporters work, dictating certain camera shots while forbidding others. ${ }^{166}$

Ideological Warfare. Besides the traditional ideological conflicts within the Muslim world, the East and West different perspectives, or the democratic versus authoritarian states conflicts, the prospect of emerging nationalism due to economic crisis or resource scarcity may create additional threats to global security. Fueling these grievances to destabilize a region provides a powerful political and military tool. 
${ }^{1}$ This study will use Jeffery Barnett's construct of a peer competitor as “a state (or alliance) capable of fielding multiple types and large numbers of both emerging and present weapons, then developing an innovative concept of operations to realize the full potential of this mix.” Barnett, Future War. Although acknowledging that they may be economic, political, and cultural competitors, this paper will assume that future competitors will not be able to compete with the US in a conventional military approach.

${ }^{2}$ Millett, "Tomorrow’s Conflicts," 42-46.

${ }^{3}$ Although in theory this strategy could also be employed by the US against a weaker state, the decision to overtly employ it would be dependent on the public support, both domestic and international. The reasons for such challenges will be exposed throughout this paper. In order to narrow the scope of the discussion, this paper will only address URW as a tool that an emergent peer competitor might wield to challenge the US.

${ }^{4}$ Liang and Xiangsui, Unrestricted Warfare.

${ }^{5}$ Ibid., xxii.

${ }^{6}$ Brimley and Singh discuss recent conflicts and suggest that the future may require a more subtle and patient approach toward the application of American power. Brimley and Singh, "Stumbling into the Future?," 315.

${ }^{7}$ The Strengths, Weaknesses, Opportunities and Threats (SWOT) model had its origins in the early 1950s. George Albert Smith and C. Roland Christensen, began questioning whether a firm's strategy matched its competitive environment. Further developments of their study introduced the relationships between internal capabilities and external possibilities to generate creative strategies to prioritize actions. ProvenModels, "SWOT analysis."

${ }^{8}$ Weigley, American Way of War, xxii.

${ }^{9}$ Linn, "The American Way of War Revisited,” 501-533.

${ }^{10}$ Boot, "New American Way of War."

${ }^{11}$ Metz, Armed Conflict in the 21st Century, viii.

${ }^{12}$ Metz, "Revolutionary Challenges for Military Strategists."

${ }^{13}$ Zinni, "Keynote Address," 23.

${ }^{14}$ Mattis and Hoffman, "Future Warfare," 18.

${ }^{15}$ Mahnken, United States Strategic Culture, 12.

${ }^{16}$ Peters, "Speed the Kill," 104.

${ }^{17}$ Cavalry spurred the fall of the Roman Empire. The crossbow and longbow challenged knights on horseback. The telegraph and railway gave Union forces an asymmetric communication and logistic advantage in the Civil War.

The airplane moved war into a third dimension, and the nuclear weapon has guaranteed the end of the Second World War. The same applies to the space superiority and cyber warfare. Lambakis, "Reconsidering Asymmetric Warfare,” 106.

${ }^{18}$ For example, "the Chinese and Turks first used gunpowder, but lost the gunpowder revolution. The French and British first used tanks, and then watched the German panzers roll right over them. The same goes in technology." Singer, "Inside the Rise of the Warbots."

${ }^{19}$ Scales, "The Second Learning Revolution," 41.

${ }^{20}$ Colonel Thomas Hammes addresses some of the advantages of the current adversaries of the US. The nature of the military organization, structured within a hierarchical framework and established bureaucracy, imposes several constrains which do not apply to potential adversaries. The rapid exploitation of commercial available technology and information services (cell phones, web sites, satellite imagery) allows a low-tech opponent to set the tempo of operations. Hammes, Sling and the Stone, 200.

${ }^{21}$ Ibid., 196.

${ }^{22}$ Gray, "How Has War Changed," 20.

${ }^{23}$ Ullman, “On War," 94.

${ }^{24}$ Boot, War Made New, 461.

${ }^{25}$ The US's military spending accounted for 45 percent of the world total in 2007, followed by the UK, China, France and Japan, with 4-5 percent each. Since 2001 US military expenditure has increased by 59 percent in real terms. SIPRI, 10.

${ }^{26}$ SIPRI, 11.

${ }^{27}$ Rosenthal, "New Rules for War?," 93.

${ }^{28}$ According to a report by the Government Accountability Office, "The Department of Defense (DOD) expects the costs to develop and procure the major weapon systems in its current portfolio to total \$1.6 trillion, \$335 billion of which is expected to be spent over the next 5 years.” GAO, 1. For example, the original development estimate for 
the Global Hawk was $\$ 967$ million, and the current estimate is $\$ 3.515$ billion. The Army’s Future Combat Systems is estimated to cost $\$ 27.955$ billion. The J-35 is projected to cost more than $\$ 40$ billion. GAO, 14 .

${ }^{29}$ Luttwak, "Dead End.”

${ }^{30}$ Luttwak, "Towards Post-Heroic Warfare," 109-22.

${ }^{31}$ Luttwak, "Dead End."

${ }^{32}$ Cordesman, The "Post Conflict" Lessons, vi.

${ }^{33}$ Peters, "The Counterrevolution in Military Affairs."

${ }^{34}$ For arguments supporting Echevarria's thesis, exposed in Toward an American Way of War, see Gray, The American Way of War, 34; Hoffman, Conflict in the $21^{\text {st }}$ Century, 24; Record, The American Way of War, 7.

${ }^{35}$ Echevarria, Toward an American Way of War, vi.

${ }^{36}$ See Colin Gray for a comprehensive discussion about the characteristics of the American way of war: apolitical; astrategic; ahistorical; problem-solving, optimistic; culturally challenged; technology dependent; focused on firepower; large-scale; aggressive, offensive; profoundly regular; impatient; logistically excellent; and sensitive to casualties. Gray, Irregular Enemies and the Essence of Strategy, 29-49.

${ }^{37}$ Browsing through history it is possible to discern a willful forgetfulness syndrome, which tends to universally apply the successes of the American way of war, disregarding the context, while forgetting lessons learned from defeat. There were several moments in history where a willful amnesia erased the lessons learned from small wars and insurgencies. That was the case of the Vietnam War where the lessons learned were ignored and deliberately forgotten. According to John Nagl, although the US Army was well aware of the deficiencies in counterinsurgency warfare, "it has failed to form a consensus on the lessons of Vietnam." Nagl, Learning to Eat Soup with a Knife, 205. Colin Gray explains this behavior by the fact that any society "will not excel in the performance of unfamiliar and profoundly unwelcome strategic missions.” Gray, The American Way of War, 35. Also Jeffrey Record expresses this frustration with limited wars, particularly counterinsurgent wars, which do not pose a vital threat to the American national interests. Record, The American Way of War, 4-5.

${ }^{38}$ Global Trends 2025 is the fourth report prepared by the National Intelligence Council that takes a long-term view of the future, with the objective to provide US policymakers with a view of how world developments could evolve, identifying opportunities and potentially negative developments that might warrant policy action.

${ }^{39}$ Global Trends 2025, 2.

40 "Because of the emergence of new global players, increasingly ineffective institutions, growth in regional blocs, advanced communications technologies, and enhanced strength of nonstate actors and networks.” Ibid., 81.

${ }^{41}$ For a detailed discussion see Zakaria, The Post-American World, and Khanna, The Second World.

${ }^{42}$ Global Trends 2025, 93.

${ }^{43}$ In the future, advanced states might engage in counterspace strikes, network attacks, and information warfare. Additionally, cyber and sabotage attacks on critical US economic, energy, and transportation infrastructures may be used. Ibid., 97.

${ }^{44}$ Ibid., 7.

${ }^{45}$ Bushnell, "The Shape of Things to Come?”

${ }^{46}$ Van Creveld, The Changing Face of War, 296.

${ }^{47}$ According to the National Science Foundation, Research and Development "comprises creative work undertaken on a systematic basis to increase the stock of knowledge-including knowledge of man, culture, and society—and its use to devise new applications." SEI 2008, Chapter 4, 66. "Industry funds about $83 \%$ of development, while the federal government funds about $16 \%$. The federal government funds about $59 \%$ of basic research, while industry funds 17\%.” SEI 2008 Appendix Table 4-10.

${ }^{48}$ Speaking during the TED 2009 (Technology, Entertainment, and Design) Peter Singer argued for the rise of robotics as a revolution in war, and that considering the current trends, by 2015 US military units might be half machine, half human. AFP, "Merciless Robots Will Fight Future Wars."

${ }^{49}$ Friedman, Hot, Flat and Crowded.

${ }^{50}$ Walton, "Countries in Tug-of-War over Arctic Resources."

${ }^{51}$ Gray, "How Has War Changed," 22.

${ }^{52}$ Information technologies will continue to enable innovating combinations of advanced precision weaponry, improving target and surveillance capabilities, enhanced command and control, and the expanding use of artificial intelligence and robotics. In the future, information itself will be targeted either by disrupting sensors or communications networks. Irregular warfare will be the primary approach in countering advanced militaries. The diffusion of technology will increase this threat. The non-military aspects of warfare will become more prevalent, 
seeking to manipulate the media in order to get public support for their cause. The employment of new forms of warfare coupled with the technological advances will increase the possibility of conflict escalation and expansion beyond traditional battlefield. Global Trends 2025, 71.

${ }^{53}$ Metz argues that, "Decisive war between major states is rapidly moving toward history’s dustbin.” Metz, Future warfare, 7. Also Van Creveld argues that, "the ability of states to go to war against each other has been diminishing since 1945.” He supports the waning of major interstate war primarily as a consequence of the introduction of nuclear weapons. Van Creveld, The Rise and Decline of the State, 337.

${ }^{54}$ Gray, "How Has War Changed,” 22. Gray further explains the current reasons for the comparative rarity of regular interstate warfare, arguing however that great power conflict is very much alive and well. Gray, Another Bloody Century, 173-87.

${ }^{55}$ Sun Tzu, The Art of War, 77.

${ }^{56}$ Ian Johnston argues that there is a Chinese historical inclination for a grand strategy of "absolute flexibility" (quan bian), revealing a preference for offensive violence over static defense. Johnston, Cultural Realism, 30. For Andrew Scobell, the "cult of defense" underlines the Chinese strategic culture within a concept of "active defense," which emphasizes a defensive posture, but actually blurs the distinction between offence and defense. Scobell, China's Use of Military Force, 193.

${ }^{57}$ Johnston, Cultural Realism, 102.

${ }^{58}$ The only terms that have been incorporated into the US's joint official doctrine are Irregular Warfare and Unconventional Warfare. The Joint Publication 1-02 defines Irregular Warfare as a violent struggle among state and non-state actors for legitimacy and influence over the relevant population(s), favoring indirect and asymmetric approaches, in order to erode an adversary's power, influence, and will. JP 1-02, 282. On the other hand, Unconventional Warfare is defined as a broad spectrum of military and paramilitary operations, including, but not limited to, guerrilla warfare, subversion, sabotage, intelligence activities, and predominantly conducted through, with, or by indigenous or surrogate forces. JP 1-02, 574. For detailed discussion about Fluid Conflicts see Leboeuf, "Fluid Conflicts: Concepts and Scenarios.” William Lind has introduced the topic of Fourth Generation Warfare in 1989. Lind, "The Changing Face of War: Into the Fourth Generation." Finally, the concept of Hybrid Warfare was developed by Frank Hoffman as a synthesis of the various tendencies of warfare. Hoffman, Conflict in the 21st Century.

${ }^{59}$ Luman, "Foreword: Welcome and Perspective on Unrestricted Warfare," 2.

${ }^{60}$ Asymmetry means the absence of a common basis of comparison in respect to a quality, or in operational terms, a capability. Meigs, "Unorthodox Thoughts about Asymmetric Warfare," 4. Steven Metz and Douglas Johnson provide a more comprehensive perspective by defining asymmetry as "acting, organizing, and thinking differently than opponents in order to maximize one's own advantages, exploit an opponent's weaknesses, attain the initiative, or gain greater freedom of action.” Metz and Johnson, Asymmetry and U.S. Military Strategy, 5.

${ }^{61}$ Meigs, "Unorthodox Thoughts about Asymmetric Warfare," 4.

${ }^{62}$ Strategically, from financial markets to transportation systems and electric power grids, standards of living worldwide depend fundamentally on integrated technical systems that are susceptible to idiosyncratic threats. Ibid., 8-9.

${ }^{63}$ Liang and Xiangsui, Unrestricted Warfare, xxii.

${ }^{64}$ Yarger, Strategic Theory, 6.

${ }^{65}$ Leboeuf, "Fluid Conflicts: Concepts and Scenarios."

${ }^{66}$ Flynt, "Threat Kingdom," 17. For example, China may possess both the capabilities and the intent to employ full spectrum measures, embodying a complete single actor threat kingdom. Ibid., 16.

${ }^{67}$ A prime example of this would be the layering of irregular and disruptive challenges such as proxy terrorist use of directed energy weapons (e.g. the Chinese ZM-87 blinding laser), against US civil aviation assets as an asymmetric response to the future fielding of US man portable air defense systems counter-measures. Bunker, Beijing, Unrestricted Warfare, and Threat Potentials, 6.

${ }^{68}$ The technological space is a metaphor, introduced by Liand and Xiangsui that in contrast with the other conventional/physical battlefields (air, land, sea, and space) owes its existence and characteristics exclusively to technology. In this context, the classical battlefield's dimensions of length, width, and height, lose all their significance. Liang and Xiangsui, Unrestricted Warfare, 31.

${ }^{69}$ Koch, “Modern Warfare," 175.

${ }^{70}$ A recent example happened during the Israeli military operations in Gaza in December 2008. In order to reduce collateral casualties, Israel's military previously warned Gaza residents of an impending airstrike (calling the residents or dropping leaflets). In other cases, "sound bombs" (detonation of bombs which creates a loud noise) 
were fired to warn people away from their houses, before the actual airstrike is made. Barzak and Friedman, "Israel bombs Gaza mosque, homes of Hamas leaders." However, in less than one week there were reports of more than 400 civilians killed due to airstrikes. Those images of endless suffering were exploited by Hamas to undermine Israel's legitimacy.

${ }^{71}$ Koch, “Modern Warfare," 175.

${ }^{72}$ When facing this kind of threat, which extends beyond the military domain, the police role becomes preeminent along with the integration of intelligence networks (civilian and military) and increasing information sharing between international agencies.

${ }^{73}$ Although not excluding the effectiveness of URW against non-liberal or authoritarian societies, in the author's perspective, URW is especially effective when employed against an open, media driven, more liberal and technological society.

${ }^{74}$ Rickli, "The Impact of Globalization on the Changing Nature of War," 5.

${ }^{75}$ The definition of critical infrastructure has changed throughout the years. It has expanded from the most basic public works to a much broader set of economic, defense, government, social, and institutional facilities. This willingness to protect a widely distributed infrastructure is difficult and expensive. As an example, by January 2006, the Department of Homeland Security's national asset database included 77,069 assets, 600 of which were classified as nationally critical. Moteff, Critical Infrastructure, 8.

${ }^{76}$ Pape, Bombing to Win.

${ }^{77}$ Liang and Xiangsui, Unrestricted Warfare, 153-171.

${ }^{78}$ Ibid., $10-13$.

${ }^{79}$ Ibid., 11.

${ }^{80}$ Ibid., 16.

${ }^{81}$ Ibid., 16.

${ }^{82}$ Ibid., 16.

${ }^{83}$ Timothy Thomas provides several examples of this concept, under development and testing by China, such as infrasound weapons which use sound waves with frequencies lower than $20 \mathrm{~Hz}$ to cause cardiac, respiratory, digestive, and central nervous system malfunctions. Additionally, microwave weapons can cause electronic interference, and lasers can be used to disable equipment or affect humans. Thomas, Cyber Silhouettes, 236.

${ }^{84}$ US Department of Defense, Annual Report to Congress, 21.

${ }^{85}$ Lowe, Transcending the Cultural Gaps, 33.

${ }^{86}$ Ibid., 33.

${ }^{87}$ Yarger, Strategic Theory, 63.

${ }^{88}$ Faber, "Combination Warfare: A New NATO Strategy."

${ }^{89}$ Robert Bunker identifies four competing schools of military in China: the Traditionalists who focus on People's War (Mao Zedong) or active defense; the Neo-Traditionalists who focus on regional power projection; the Military Revolutionists who focus on high tech 2030 type change; and Unrestricted Warfare advocates. Bunker, Beijing, Unrestricted Warfare, and Threat Potentials, 3. For more detailed analysis about China's military doctrine and strategy see the 2008 US Department of Defense, Annual Report to Congress.

${ }^{90}$ Lemos, "Defacements Rise in China Hacker War."

${ }^{91}$ Kirk, "Estonia, Poland Help Georgia Fight Cyber Attacks."

${ }^{92}$ Harris, "China’s Cyber-Militia."

${ }^{93}$ National Defense Strategy, 22. As an evidence of this, in January 2007, - three years sooner than predicted by US intelligence agencies, China successfully employed a missile to destroy an orbiting satellite, demonstrating its operational offensive space-denial capability. Krepinevich and Martinage, The Challenges to US National Security, 35

${ }^{94}$ Metz, "Revolutionary Challenges for Military Strategists."

${ }^{95}$ US Department of Defense, Annual Report to Congress, 20.

${ }^{96}$ Ibid., 18.

${ }^{97}$ Ibid., 22.

${ }^{98}$ Kelly and Kilcullen, “Chaos Versus Predictability,” 71. For example, when Pearl Harbor was attacked most of the Japanese leaders were not able to predict the uniting effect on the US's society which would eventually lead to the declaration of war. Additionally, the interconnected nature of advanced societies constrains the options available to an adversary. For example, in the event of an attack on the US's stock market or banking system, wouldn't that have ripple effects to the economy of the attacker?

${ }^{99}$ AFDD 2, 16. 
${ }^{100}$ Rasmussen, The Risk Society at War, 157.

${ }^{101}$ Van Creveld, The Transformation of War, 225.

102 Ibid., 225.

103 These multinational companies offer a variety of security services that can include the use of military force. A detailed list of such companies and missions can be found in the site http://www.privatemilitary.org. Peter Singer addresses the rising of privatized military industry which changes the ways wars are fought. Introducing profit as a fighting objective challenges the ethics of the nation-state and the military institutions. For a comprehensive analysis of the Private Military Companies see Singer, Corporate Warriors.

${ }^{104}$ Hammes, "Fourth Generation Warfare Evolves: Fifth Emerges,” 18.

105 Ibid., 18.

106 Testifying before the House Appropriations Subcommittee on Defense on the impact of private military contractors on the conduct of the Iraq War, Jeremy Scahill stated that in 2007 there were "at least 126,000 private personnel deployed alongside the official armed forces. These private forces effectively double the size of the occupation force." Scahill, "Outsourcing the War.”

${ }^{107}$ Van Creveld, The Transformation of War, 204.

${ }^{108}$ For a seminal study about Risk Society see Beck, Ulrich. Risk Society.

${ }^{109}$ Cultural, drug, economic aid, environmental, financial, international law, media, network, psychological, resource, smuggling, technological, and terrorism. Smyth, “Discussion Group Insights and Recommendations,” 338.

${ }^{110}$ Kellman, "Bioviolence: A Growing Threat."

${ }^{111}$ Max Boot, War Made New, 459.

112 Kaplan, "On Forgetting the Obvious.”

113 Rasmussen, The Risk Society at War, 4.

${ }^{114}$ Rickli, "The Impact of Globalization on the Changing Nature of War."

${ }^{115}$ Krepinevich and Martinage, The Challenges to US National Security, 24.

${ }^{116}$ Flynn, "The Neglected Home Front.”

${ }^{117}$ US Department of Defense, Annual Report to Congress, 6.

${ }_{118}$ McAfee, Virtual Criminology Report 2008, 12-13.

${ }^{119}$ Bunker, Beijing, Unrestricted Warfare and Threat Potentials.

${ }^{120}$ Max Boot describes possible interpretations within the URW framework: “The anti-Japanese riots that swept China in April? That would be psychological warfare against a major Asian rival. The stage-managed protests in 1999, after the U.S. accidentally bombed the Chinese Embassy in Belgrade, fall into the same category. The bid by the state-owned China National Offshore Oil Co., to acquire Unocal? Resource warfare. Attempts by China's spy apparatus to infiltrate U.S. high-tech firms and defense contractors? Technological warfare. China siding against the U.S. in the U.N. Security Council over the invasion of Iraq? International law warfare. Gen. Zhu's threat to nuke the U.S.? Media warfare.” Boot, "China’s Stealth War on the U.S.”

${ }^{121}$ Unilateral legal constraints include such measures as the Posse Comitatus Act, arms control conventions such as the Biological Weapons Convention and Intermediate Nuclear Forces Treaty, and the Executive Order banning assassination. Lambakis, "Reconsidering Asymmetric Warfare,” 103. Just War theory seeks to legitimize state’s violence, justifying its ends and imposing limitations to the means. It aims to answer two fundamental questions: when is war permissible (jus ad bellum); and what are the limitations when waging war (jus in bello). For further discussing about Just War theory see the seminal work of Michael Walzer, Just and Unjust Wars.

${ }^{122}$ Marcella and Fought, “Teaching Strategy in the 21st Century,” 56.

${ }^{123}$ Hunter, A New Grand Strategy for the United States, 17.

${ }^{124}$ Marcella, "National Security and the Interagency Process,” 30.

${ }^{125}$ Boot, War Made New, 460.

${ }^{126}$ Stephen Biddle addresses the lack of a clear definition of the threat, its interests as well as the desired end state. This ambiguity hinders an effective strategic thought process. Biddle, American Grand Strategy After 9/11.

${ }^{127}$ Marcella, “National Security and the Interagency Process,” 29.

${ }^{128}$ Regarding manpower, the "Department of Defense is about 210 times larger than USAID and State combined.” Kilcullen, "New Paradigms for 21st Century Conflict.”

${ }^{129}$ Marcella, "National Security and the Interagency Process," 44.

${ }^{130}$ Several reports mention the lack of an institutionalized process for long range national security. Additionally, there is a growing concern in the literature about the need to mesh all the levers and instruments of power. Michèle Flournoy and Shawn Brimley highlight the lack of a mechanism to ensure that the president's policy priorities are 
fulfilled. Flournoy and Brimley, Strategic Planning for U.S. National Security, 19. The same view is shared by Aaron Friedberg, stating that the US government has lost the capacity to conduct national strategic planning, mainly because there is no entity which can integrate the partial strategies into a coherent, comprehensive whole. According to him, this has lead to a loss of efficiency, expressed in misallocated resources, suboptimal policies, duplication of effort, lost opportunities, and costly improvisations. Friedberg, "Strengthening U.S. Strategic Planning," 47. For further discussion about the interagency influence in national security see Marcella, Affairs of the State. For an overview of the current national security reform debates, see Dale, Serafino and Towell, Organizing the U.S. Government for National Security. For an updated reflection about the imperatives for interagency action see the proceedings of the 2009 URW Symposium, organized by the Johns Hopkins University, which identifies "integrated strategy, analysis, and technology options that enhance interagency capabilities to respond to four potential unrestricted lines of attack—cyber, resource, economic/financial, and terrorist threats.” 2009 Unrestricted Warfare Symposium Web page.

${ }^{131}$ Hunter, Integrating Instruments of Power and Influence, 10.

${ }_{132}$ Dale, National Security Strategy, 1.

${ }^{133}$ Alberts and Hayes. Power to the Edge, 233.

${ }^{134}$ Marcella, "National Security and the Interagency Process," 46.

${ }^{135}$ Capstone Concept for Joint Operation, 34.

${ }^{136}$ Douhet, The Command of the Air, 30.

${ }^{137}$ Hart, Strategy, 82.

${ }^{138}$ Clausewitz, On War, 85.

${ }^{139}$ Ibid., 593.

${ }^{140}$ Liang and Xiangsui, Unrestricted Warfare, 38-43.

${ }^{141}$ SIPRI, 16.

142 Global Trends 2025, x.

${ }^{143}$ Van Creveld, Modern Conventional Warfare: an Overview, 13.

${ }^{144}$ SIPRI, 19.

${ }^{145}$ Armistead, Information Operations, 122.

${ }^{146}$ JP 1-02, 182.

147 Thomas, Cyber Silhouettes.

148 JP 1-02, 235.

${ }^{149}$ Hammes, The Sling and the Stone, 259.

${ }^{150}$ McAffee Report, Unsecured Economies: Protecting Vital Information, 7.

151 "McAfee, Inc. Research Shows Global Recession Increasing Risks to Intellectual Property"

${ }^{152}$ McAffee Report, Unsecured Economies: Protecting Vital Information, 8.

${ }^{153}$ Ibid., 23.

154 Thomas, Cyber Silhouettes, 243.

${ }^{155}$ Associated Press, "U.S. says more warfare technology being smuggled to China and Iran."

${ }^{156}$ Kan, Drugs and Contemporary Warfare, xi.

${ }^{157}$ Liang and Xiangsui, Unrestricted Warfare, 40.

158 There are several examples where the US has blocked overseas bank accounts of North Korean, Iranian, and Russian companies involved in illicit activities such as nuclear and conventional weapons proliferation. Moreover, targeting the funding of terrorists and supporting organizations has provided an effective strategy to deal with this threat. Bracken, "Financial Warfare."

${ }^{159}$ Paul Bracken estimates that the international money movements amount to \$2.5 trillion per day. Ibid.

${ }^{160}$ Ibid.

${ }^{161}$ Ibid.

${ }^{162}$ Global Trends 2025, viii.

${ }^{163}$ Ibid., $\mathrm{x}$.

${ }^{164}$ Associated Press, "Russia hosts ex-Soviet security summit."

${ }^{165}$ US Department of Defense, Annual Report to Congress, 19.

${ }^{166}$ Koch, “Modern Warfare,” 179. 


\section{Bibliography}

Adams, David A. “Managing China's Transition.” Proceedings Magazine vol. 129, issue 7 (July 2003).

Agence France-Presse. "Merciless Robots Will Fight Future Wars.” AFP. 5 February 2009. http://www.google.com/hostednews/afp/article/ALeqM5iYmGo87FaeVFdRRaP39VIKM9hqA.

Air Force Doctrine Document 2. Operations and Organization. Maxwell AFB, AL: Air Force Doctrine Development and Education Center, 3 Apr 2007.

Alberts, David, and Richard Hayes. Power to the Edge. Washington DC: CCRP, 2003.

Armistead, Leigh, ed. Information Operations: Warfare and the Hard Reality of Soft Power. Washington, DC: Potomac Books, 2004.

Associated Press. "Russia hosts ex-Soviet security summit." International Herald Tribune. 4 February 2009.

http://www.iht.com/articles/ap/2009/02/04/europe/EU-Russia-Ex-Soviet-Summit.php. . "U.S. says more warfare technology being smuggled to China and Iran." International Herald Tribune. 11 October 2007. http://www.iht.com/articles/ap/2007/10/11/america/NA-GEN-US-Terror-Exports.php.

Barnett, Jeffery R. Future War: An Assessment of Aerospace Campaigns in 2010. Maxwell AFB, AL: Air University Press, 1996.

Barzak, Ibrahim, and Matti Friedman. "Israel bombs Gaza mosque, homes of Hamas leaders.” Associated Press, 2 January 2009. http://www.chron.com/disp/story.mpl/front/6190854.html.

Basilici, Steven P., and Jeremy Simmons. Transformation: A Bold Case for Unconventional Warfare. Monterey, CA: Naval Postgraduate School, 2004.

Beck, Ulrich. Risk Society: Towards a New Modernity. London: Sage, 1992.

Biddle, Stephen. American Grand Strategy After 9/11: An Assessment. Carlisle, PA: Strategic Studies Institute, U.S. Army War College, 2005.

Boot, Max. “China’s stealth war on the US.” Los Angeles Times Online, 20 July 2005. http://articles.latimes.com/2005/jul/20/opinion/oe-boot20. 
. “The New American Way of War.” Foreign Affairs vol. 82, no. 4 (July/August 2003). http://www.foreignaffairs.org/20030701faessay15404/max-boot/the-new-americanway-of-war.html.

. The Savage Wars of Peace: Small Wars and the Rise of American Power. New York: Basic Books, 2002.

. War Made New. London: Gotham Books, 2006.

Bracken, Paul. “Financial Warfare.” Foreign Policy Research Institute, September 2007. http://www.fpri.org/enotes/200709.bracken.financialwarfare.html.

Brimley, Shawn, and Vikram Singh. "Stumbling into the Future? The Indirect Approach and American Strategy.” Orbis 52, issue 2 (Spring 2008): 312-331.

Bunker, Robert J. Testimony Before the U.S.-China Economic and Security Review Commission: Beijing, Unrestricted Warfare, and Threat Potentials. 29 March 2007. www.uscc.gov/hearings/2007hearings/transcripts/mar_29_30/bunker.pdf.

Bushnell, Dennis M. “The Shape of Things to Come?” Undersea Warfare vol. 3, no. 2 (Winter 2001). http://www.navy.mil/navydata/cno/n87/usw/issue_10/bushnell_shape.html.

Clausewitz, Carl von. On War. Edited and translated by Michael Howard and Peter Paret. Princeton, NJ: Princeton University Press, 1989.

Cordesman, Anthony H. The "Post Conflict" Lessons of Iraq and Afghanistan: Testimony to the Senate Foreign Relations Committee. 19 May 2004. Washington, DC: Center for Strategic and International Studies.

Dale, Catherine, Nina Serafino, and Pat Towell. Organizing the U.S. Government for National Security: Overview of the Interagency Reform Debates. Washington DC: Congressional Research Service, Library of Congress, 2008. (CRS Report for Congress, RL34455).

Dale, Catherine. National Security Strategy: Legislative Mandates, Execution to Date, and Considerations for Congress. Washington DC: Congressional Research Service, Library of Congress, 2008. (CRS Report for Congress, RL34505).

Douhet, Giulio. The Command of the Air. Edited by Richard H. Kohn and Joseph P. Harahan. Washington, DC: US Government Printing Office, 1983.

Echevarria II, Antulio J. Toward an American Way of War. Carlisle, PA: US Army War College, Strategic Studies Institute, 2004.

Faber, Peter, Radamanthis Fountoulakis, Biagio Frugarello, and Istvan Kadar. "Combination Warfare: A New NATO Strategy for the Asymmetric Risks and Challenges of the 21st 
Century.” In Essays by Senior Courses 100 and 101 (NATO Defense College Essay Series, No.4). Edited by Dieter Ose and Peter Faber. Rome: NATO Defense College, 2003.

Flournoy, Michèle A., and Shawn W. Brimley. Strategic Planning for U.S. National Security: A Project Solarium for the 21st Century. Princeton, NJ: Woodrow Wilson School of Public and International Affairs, 2006.

Flynn, Stephen E. “The Neglected Home Front.” Foreign Affairs 83, no. 5 (September/October 2004). http://www.foreignaffairs.org/20040901faessay83504/stephen-e-flynn/the-neglectedhome-front.html.

Flynt, Bill. “Threat Kingdom.” Military Review (July-August 2000): 12-21.

Freedman, Lawrence. The Transformation of Strategic Affairs. Adelphi Paper no. 379. The International Institute for Strategic Studies, Routledge, 2006.

Friedberg, Aaron L. “Strengthening U.S. Strategic Planning.” The Washington Quarterly 31:1. Winter 2007-08): 47-60.

Friedman, Thomas. Hot, Flat and Crowded. New York: Farrar, Straus and Giroux, 2008.

Gray, Colin S. Another Bloody Century. London: Phoenix Press, 2005.

. “How Has War Changed Since the End of the Cold War?” Parameters (Spring 2005): 14-26.

. "The American Way of War: Critique and Implications.” In Rethinking the Principles of War. Edited by Anthony D. Mc-Ivor. Annapolis, MD: Naval Institute Press, 2005.

Irregular Enemies and the Essence of Strategy: Can the American Way of War Adapt? Carlisle, PA: US Army War College, Strategic Studies Institute, 2006.

Hammes, Thomas X. "Fourth Generation Warfare Evolves: Fifth Emerges.” Military Review, (May/June 2007): 14-23.

. The Sling and the Stone: On War in the 21st Century. St. Paul, MN: Zenith, 2004.

Harris, Shane. “China’s Cyber-Militia.” National Journal Magazine, 31 May 2008, http://www.nationaljournal.com/njmagazine/cs_20080531_6948.php.

Hart, B.H. Liddell. Strategy: The Indirect Approach. New York: Frederick A. Praeger, 1954.

Hoffman, Frank G. Conflict in the 21st Century: The Rise of Hybrid Wars. Arlington, VA: Potomac Institute for Policy Studies, 2007. 
Hunter, Robert E. A New Grand Strategy for the United States: Testimony Presented Before the House Armed Services Committee, Subcommittee on Oversight and Investigations. 31 July 2008. Santa Monica, CA: RAND Corporation, 2008.

Hunter, Robert E., Edward Gnehm, and George Joulwan. Integrating Instruments of Power and Influence: Lessons Learned and Best Practices. Santa Monica, CA: RAND Corporation, 2008.

Johns Hopkins University. “2009 Unrestricted Warfare Symposium.”

http://www.jhuapl.edu/urw_symposium/Default.aspx.

Johnston, Iain. Cultural Realism: Strategic Culture and Grand Strategy in Chinese Culture. Princeton, NJ: Princeton University Press, 1998.

Kan, Paul Rexton. Drugs and Contemporary Warfare. Dulles, VA: Potomac Books, 2009.

Kaplan, Robert D. “On Forgetting the Obvious.” The American Interest 2, no. 6 (July-August 2007). http://www.the-american-interest.com/ai2/article.cfm?Id=289\&MId=14.

Kellman, Barry. “Bioviolence: A Growing Threat.” The Futurist 42, no. 3 (May-June 2008).

Kelly, Justin, and David Kilcullen, "Chaos Versus Predictability: A Critique of Effects-Based Operations.” Security Challenges 2, no. 1 (April 2006): 63-73.

Khanna, Parag. The Second World: Empires and Influence in the New Global Order. New York: Random House, 2008.

Kilcullen, David J. “New Paradigms for 21st Century Conflict.” eJournal USA, May 2007. http://usinfo.state.gov/journals/itps/0507/ijpe/kilcullen.htm.

Kirk, Jeremy. “Estonia, Poland Help Georgia Fight Cyber Attacks.” IDG News Service, 12 August 2008. http://www.cio.com/article/443314/Estonia_Poland_Help_Georgia_Fight_Cyber_Attacks.

Koch, Stéphane. “Modern Warfare': The Battle for Public Opinion.” Défense nationale et sécurité collective, Paris: Committee for National Defence Studies, ${ }^{\circ}{ }^{\circ}$ 10, October 2006.

Krepinevich, Andrew, Robert Martinage, and Robert Work. The Challenges to US National Security: Strategy for the Long Haul. Washington DC: Center for Strategic and Budgetary Assessments, 2008.

Lambakis, Steve. “Reconsidering Asymmetric Warfare.” Joint Forces Quarterly issue 36 (1 $1^{\text {st }}$ Quarter 2005): 102-108. 
Leboeuf, Aline. "Fluid Conflicts: Concepts and Scenarios”. Politique étrangère (September 2005). Translated by Roger Leverdier. Paris: Institute Français du Royaume Uni. http://www.diplomatie.gouv.fr/fr/IMG/pdf/0404-LEBOEUF-GB-2.pdf.

Lemos, Robert. “Defacements Rise in China Hacker War.” CNET News, 30 April 2001. http://news.cnet.com/2100-1001-256732.html.

Liang, Qiao, and Wang Xiangsui. Unrestricted Warfare. Panama: Pan American Publishing Company, 2002.

Lind, William S., et al. “The Changing Face of War: Into the Fourth Generation.” Marine Corps Gazette (October 1989): 22-26.

Linn, Brian M. “The American Way of War Revisited.” Journal of Military History 66, no. 2 (April 2002): 501-533.

Lowe, Edwin. Transcending the Cultural Gaps in 21st Century Analysis and Planning: The Real Revolution in Military Affairs. Canberra: The Australian National University, Strategic and Defence Studies Centre, 2004.

Luman, Ronald. "Foreword: Welcome and Perspective on Unrestricted Warfare.” In Proceedings of the Unrestricted Warfare Symposium. Edited by Ronald Luman. Laurel, MD: Johns Hopkins University/Applied Physics Lab, 2008.

Luttwak, Edward N. "Dead End: Counterinsurgency Warfare as Military Malpractice.” Harper’s Magazine (February 2007). http://harpers.org/archive/2007/02/0081384.

22.

. “Towards Post-Heroic Warfare.” Foreign Affairs 74, no.3 (May/June 1995): 109-

Mahnken, Thomas G. United States Strategic Culture. Fort Belvoir, VA: Defense Threat Reduction Agency, 2006.

Marcella, Gabriel, and Stephen Fought. "Teaching Strategy in the 21st Century.” Joint Forces Quarterly issue 52 ( $1^{\text {st }}$ Quarter 2009): 56-60.

Marcella, Gabriel, ed. Affairs of the State: The Interagency and National Security. Carlisle, PA: Strategic Studies Institute, US Army War College, 2008.

Marcella, Gabriel. "National Security and the Interagency Process.” In US Army War College Guide to National Security Issues, Vol II: National Security Policy and Strategy, $3{ }^{\text {rd }}$ Edition, Edited by Bartholomees Jr., Boone. Department of National Security and Strategy, Carlisle, PA: Strategic Studies Institute, US Army War College, 2008.

Mattis, James N., and Frank Hoffman. "Future Warfare: The Rise of Hybrid Warfare.” Proceedings Magazine (November 2005): 18-19. 
McAfee Press Release. "McAfee, Inc. Research Shows Global Recession Increasing Risks to Intellectual Property.” 29 January 2009. http://www.mcafee.com/us/about/press/corporate/2009/20090129_063500_j.html.

McAfee Report. Unsecured Economies: Protecting Vital Information. Santa Clara, CA: McAfee, Inc, 2009.

. Virtual Criminology 2008. Santa Clara, CA: McAfee, Inc, 2008.

Meigs, Montgomery C. “Unorthodox Thoughts about Asymmetric Warfare.” Parameters (Summer 2003): 4-18.

Metz, Steven. "Revolutionary Challenges for Military Strategists: The Time of Thermidor." Strategic Review for Southern Africa (May 2005).

http://findarticles.com/p/articles/mi_hb1402/is_1_27/ai_n29201232.

Armed Conflict in the 21st Century: The Information Revolution and Post-Modern Warfare. Carlisle, PA: US Army War College, Strategic Studies Institute, 2000.

Metz, Steven, and Douglas V. Johnson II. Asymmetry and U.S. Military Strategy: Definition, Background, and Strategic Concepts. Carlisle, PA: Strategic Studies Institute, 2001.

Metz, Steven, and Raymond A. Millen. Future War/Future Battlespace: The Strategic Role of American Landpower. Carlisle, PA: US Army War College, Strategic Studies Institute, 2003.

Millett, Stephen M. “Tomorrow’s Conflicts: Faster, Safer, Casualty-Free.” The Futurist 37, no. 6 (November-December 2003).

Moteff, John. Critical Infrastructure: The National Asset Database. Washington DC: Congressional Research Service, Library of Congress, 2007. (CRS Report for Congress, RL33648).

Nagl, John A. Learning to Eat Soup with a Knife: Counterinsurgency Lessons from Malaya and Vietnam. Chicago: University of Chicago Press, 2002.

National Intelligence Council. Global Trends 2025: A Transformed World. Washington, DC: Government Printing Office, 2008.

National Science Foundation. Science and Engineering Indicators 2008. Washington, DC: Division of Science Resource Statistics, 2008.

Office of the President of the United States. The National Security Strategy of the United States of America. Washington, DC. March 2006. 
Pape, Robert A. Bombing to Win: Air Power and Coercion in War. Ithaca, NY: Cornell University Press, 1996.

Peters, Ralph. “Speed the Kill.” In Rethinking the Principles of War. Edited by Anthony D. Mc-Ivor. Annapolis, MD: Naval Institute Press, 2005.

. “The Counterrevolution in Military Affairs.” Weekly Standard 11, issue 20 (6 February 2006).

http://www.weeklystandard.com/Content/Public/Articles/000/000/006/649qrsob.asp.

Private Military Companies Web Link. http://www.privatemilitary.org.

ProvenModels. “SWOT Analysis.” http://www.provenmodels.com/37/swot-analysis/learnedchristensen-andrews-guth.

Rasmussen, Mikkel. The Risk Society. New York: Cambridge University Press, 2006.

Record, Jeffrey. The American Way of War: Cultural Barriers to Successful Counterinsurgency. Policy Analysis 577. Washington DC: CATO Institute, 2006.

Rosenthal, Joel. “New Rules for War?” Naval War College Review LVII, no. 3 (SummerAutumn 2004).

Santoli, Albert. Testimony before the U.S.-China Economic and Security Review Commission: China's Strategic Reach into Latin America. 21 July 2005.

http://www.uscc.gov/hearings/2005hearings/written_testimonies/05_07_21_22wrts/santoli_a lbert_wrts.htm.

Scahill, Jeremy. “Outsourcing the War.” http://www.thenation.com/doc/20070528/scahill.

Scales, Robert. "The Second Learning Revolution.” In Rethinking the Principles of War. Edited by Anthony D. Mc-Ivor. Annapolis, MD: Naval Institute Press, 2005.

Scobell, Andrew. China's Use of Military Force: Beyond the Great Wall and the Long March. New York: Cambridge University Press, 2003.

Singer, Peter W. Corporate Warriors: The Rise of the Privatized Military Industry. Ithaca: Cornell University Press, 2003. . "Inside the Rise of the Warbots.” Wired.com. 4 February 2009. http://blog.wired.com/defense/2009/02/peter-singers-w.html. - Wired for War. New York: Penguin Press, 2009. 
Smyth, Edward A. "Discussion Group Insights and Recommendations." In Proceedings of the Unrestricted Warfare Symposium. Edited by Ronald Luman. Laurel, MD: Johns Hopkins University/Applied Physics Lab, 2006.

Stockholm International Peace Research Institute (SIPRI). SIPRI Yearbook 2008 Summary: Armaments, Disarmament and International Security. International Peace Research Institute. Oxford: Oxford University Press, 2008.

Thomas, Timothy L. Cyber Silhouettes. Fort Leavenworth, KS: Foreign Military Studies Office, 2005.

Tzu, Sun. The Art of War. Translated by Samuel B. Griffith. Oxford: Oxford University Press, 1963.

Ullman, Harlan. “On War.” In Rethinking the Principles of War. Edited by Anthony D. McIvor. Annapolis, MD: Naval Institute Press, 2005.

US Government Accountability Office. Report to the Committee on Armed Services, U.S. Senate, Defense Acquisitions: A Knowledge-Based Funding Approach Could Improve Major Weapon System Program Outcomes. Washington DC: Government Printing Office, 2008.

US Department of Defense. Annual Report to Congress: Military Power of the People's Republic of China 2008. Washington, DC: Office of the Secretary of Defense, 2008.

. Capstone Concept for Joint Operation, Version 3.0. Washington, DC: Department of Defense, 15 January 2009.

. Joint Publication 1-02. The Department of Defense Dictionary of Military and Associated Terms, 12 April 2001 (As Amended Through 17 October 2008).

. National Defense Strategy of the United States of America. Washington, DC: Department of Defense, June 2008.

. National Military Strategy of the United States of America. Washington, DC: Department of Defense, May 2004.

Van Creveld, Martin. Modern Conventional Warfare: An Overview. The NIC 2020 Project Workshop "Changing Nature of Warfare”. Washington DC: National Intelligence Council, 2004.

. The Changing Face of War. New York: Ballantine Books, 2006.

. The Rise and Decline of the State. Cambridge: Cambridge University Press, 1999.

. The Transformation of War. New York: Free Press, 1991. 
Walton, Marsha. "Countries in Tug-of-War Over Arctic Resources.” CNN.com, 2 January 2009. http://www.cnn.com/2009/TECH/science/01/02/arctic.rights.dispute/index.html.

Walzer, Michael. Just and Unjust Wars. New York, NY: Basic Books, 1977.

Weigley, Russell F. The American Way of War: A History of United States Military Strategy and Policy. Bloomington, IN: Indiana University Press, 1973.

Yarger, Harry R. Strategic Theory for the 21st Century: The Little Book on Big Strategy. Carlisle, PA: Strategic Studies Institute, 2006.

Zakaria, Fareed. The Post-American World. New York: Norton \& Company, 2008.

Zinni, Anthony. "Keynote Address." In Proceedings of the Unrestricted Warfare Symposium. Edited by Ronald Luman. Laurel, MD: Johns Hopkins University/Applied Physics Lab, 2006. 